\title{
Middle Miocene (Badenian) chondrichthyan and osteichthyan remains from St. Margarethen (eastern Austria) in the vertebrate palaeontological collection of the Hungarian Natural History Museum
}

\author{
Márton SzABó \\ Department of Palaeontology and Geology, Hungarian Natural History Museum, \\ H-1083 Budapest, Ludovika tér 2, Hungary.E-mail:szabo.marton.pisces@gmail.com
}

\begin{abstract}
To actualize the available data regarding Cenozoic fish materials housed in the vertebrate fossil collection of the Hungarian Natural History Museum (HNHM), Middle Miocene (Badenian) chondrichthyan remains, unearthed at St. Margarethen (Burgenland, eastern Austria) are revised in detail. Among the specimens, a mislabelled, slightly disarticulated, partial dentition surrounded by associable placoid scales and portions of suggested cartilage, referred to a juvenile individual of an indeterminate Carchariidae or Odontaspididae has been found. This specimen represents the first articulated shark fossil ever discovered in the Miocene of the Central Paratethys. The material also includes a large-sized, pathological tooth of Otodus (Megaselachus) megalodon, which is the largest and most spectacular of all Otodus (Megaselachus) megalodon teeth of the HNHM collection. The HNHM collection includes osteichthyan remains, also unearthed at St. Margarethen, but these specimens are only shortly mentioned. Although the Middle Miocene marine vertebrate fossils of St. Margarethen are actively investigated for over one and a half centuries, the HNHM material adds new and important data to our knowledge on the locality's chondrichthyan fauna. The present paper also highlights the importance of accurate re-investigation of museum fossil collections. With 112 figures.
\end{abstract}

Key words - Austria, Badenian, Hungarian Natural History Museum, Middle Miocene, Otodus megalodon, St. Margarethen

\section{INTRODUCTION}

The Central Paratethys was a part of a large epicontinental sea, the Paratethys, which was isolated from the Tethys Ocean from the late Eocene to the early Oligocene (BÁLDI 1983; RöGL \& STEININGER 1983; RögL 1998). Thanks to the rich fossil materials housed in museum collections around Europe, the Badenian fish faunas of the Central Paratethys are quite elaborated (SCHULTZ 2013 and references therein; SzABó \& Kocsis 2016 and references therein). Among them, some localities are very long-known, e.g. the fossiliferous beds nearby St. Margarethen (eastern Austria) have been known since the first half of the 19th century (see MÜNSTER 1846). 
The most remarkable feature of the Leitha Limestone exposed in the vicinity of St. Margarethen is the richness and the extraordinarily good preservation of the diverse fossil fauna, which consists of bivalves, bryozoans, brachiopods, crustaceans, echinoids, chondrichthyans, and well-preserved articulated fish skeletons. Such a remarkable preservation of the fossils seems to be related to the concurrent effect of episodic events of bottom hypoxia and persistent lack of water agitation (SCHMID et al. 2001). A large collection of well-preserved fish fossils unearthed at the surrounding quarries of St. Margarethen is housed in the Naturhistorisches Museum in Vienna (CARnevale \& Harzhauser 2013; Carnevale \& Tyler 2014). A comprehensive analysis of this extremely rich ichthyofauna (see in CHANET \& SCHUltz 1994: 96 and references therein; SCHULTZ 2013 and references therein) is yet to come.

The goal of this study is to describe (or re-describe) the chondrichthyan fossils unearthed at St. Margarethen, now housed in the vertebrate palaeontological collection of the Hungarian Natural History Museum (HNHM; Budapest). However, the material includes bony fish fossils as well, these specimens are only shortly mentioned, and their detailed elaboration is beyond the scope of the present paper. Apart from the palaeontological importance of the chondrichthyan and osteichthyan specimens, their place in the history of the HNHM is also detailed.

\section{LOCALITY AND GEOLOGICAL SETTING}

The fossils documented herein were collected in the vicinity of St. Margarethen (Burgenland, eastern Austria) (Fig. 1). The village lies in the EisenstadtSopron Basin, which is widely considered as a sub-basin of the Vienna Basin (e.g. SAUER et al. 1992). The basin is bordered by the Leitha Mountains from north, the Fertőrákos-Ruster Downs from east, the Sopron Hills from south and the Rosalia Mountains from west (SCHMid et al. 2001).

There is no inventoried data allowing a more precise identification of the exact quarry, where the fossils were found, and since several pits are located along the road, going from the village of St. Margarethen to Rust (Kummer, Roman, and Hummel quarries; Fig. 2), the site which yielded the fossils remains obscure.

Roman and Kummer quarries mostly expose deposits usually referred to as Leitha Limestone in the regional literature (RIEgL \& PilleR 2000; CARNevale \& Collette 2014). This corallinacean limestone was dated to the Badenian of the Central Paratethys stratigraphy (Bulimina-Bolivina Zone after PAPP et al. 1978), corresponding to the Langhian/Serravallian boundary of the global chronostratigraphic chart (PAPP et al. 1978; SCHMID et al. 2001; KovÁČ et al. 2007; RöGL et al. 2008) (Fig. 3). It is noteworthy that the lower limit of the Badenian 


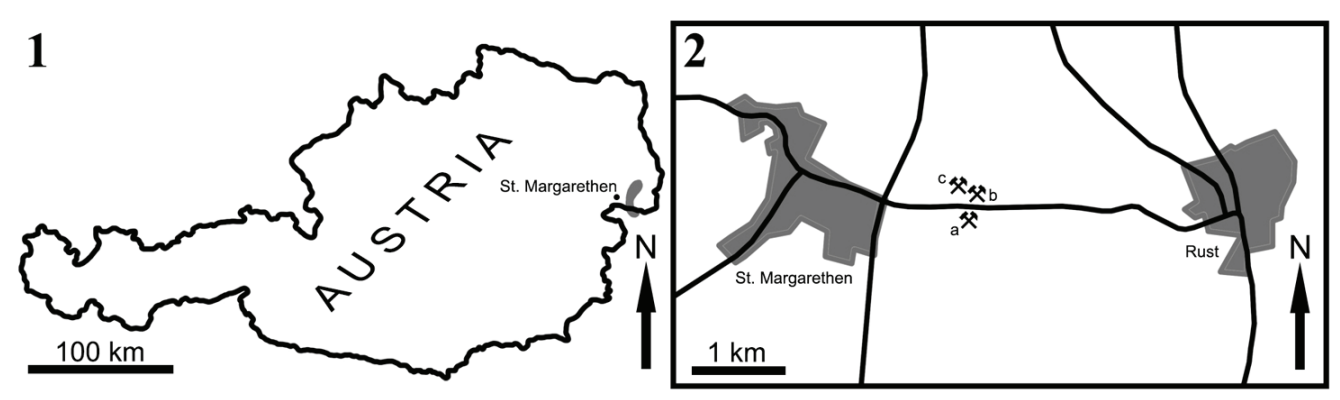

Figs 1-2. Location of the studied localities. - Fig. 1. The location of St. Margarethen in Austria. - Fig. 2. The vicinity of St. Margarethen, showing three famous quarries along the road from St. Margarethen to Rust, with Middle Miocene deposits exposed. $a=$ Kummer quarry; $b=$ Roman quarry; $\mathrm{c}=$ Hummel quarry

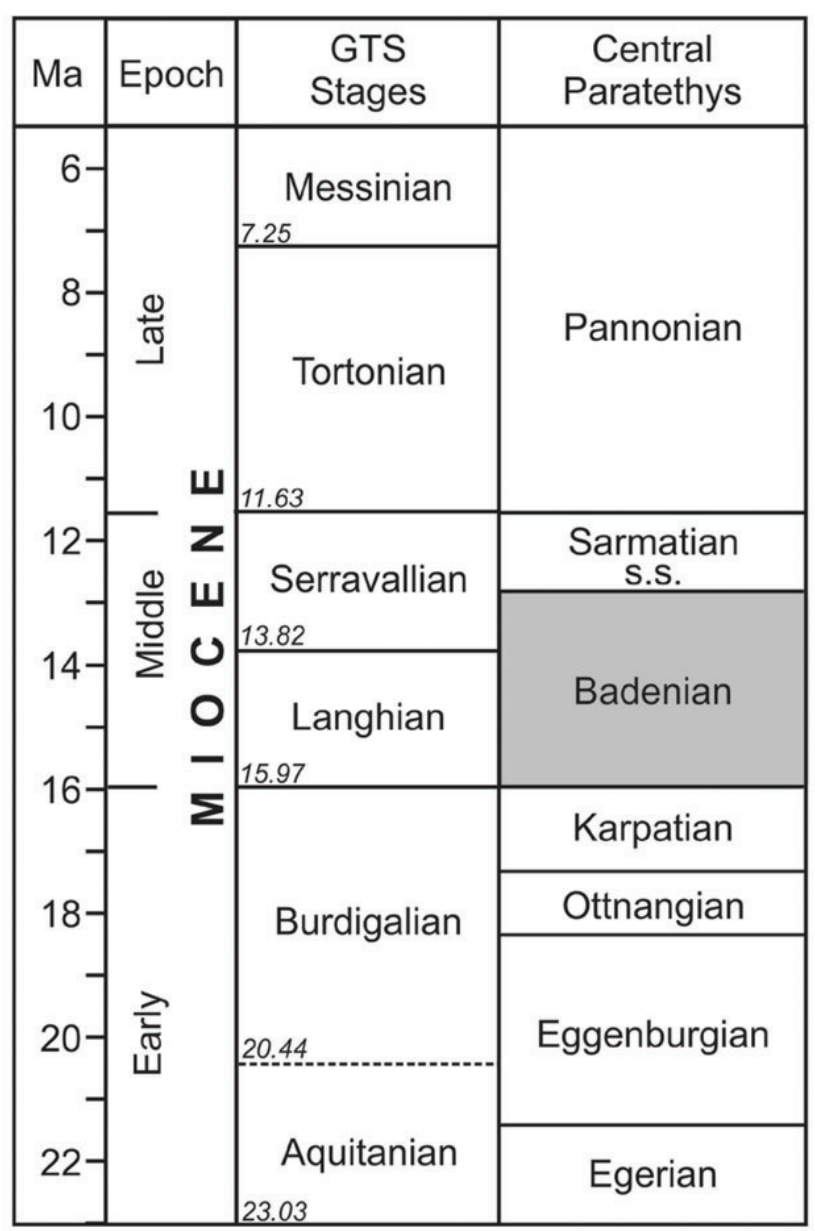

Fig. 3. Miocene chronostratigraphy comparing global stratigraphic chart stages and Central Paratethys stages (modified after Gradstein et al. 2012) 
subdivision has been recently proposed to be before the Langhian/Burdigalian boundary by HOHENEGGER et al. (2014).

The Leitha Limestone is the most characteristic and wide-spread shallow water carbonate in the Badenian (RIEGL \& PILleR 2000). It has been known since the first half of the 19th century (KEFERSTEIN 1828), its name is used also outside the Vienna Basin (STUDENCKI 1988). The Leitha Limestone is characterized by the occurrence of coralline algae in various growth forms, after which the unit is frequently called as Nullipora, Lithothamnium or Lithothamnion limestone (e.g. Wessely 1983; SAuer et al. 1992; Piller 1994). However, Papp \& Steininger (in PAPp et al. 1978) redefined the term Leitha Limestone, RiegL \& Piller (2000) still used it only in its descriptive manner to avoid further misidentifications. Based on a study of the Leitha Limestone in the EisenstadtSopron Basin, Dullo (1983) recognized 10 types of microfacies.

Coral buildups of limited size are developed only locally, the best-developed coral buildups are present at the southern tip of the Leitha Mountains where the limestones reach the greatest spatial extent and their greatest thickness (about 50 m; Tollmann 1985). During the Badenian, the tips of the Leitha Mountains reached above sea-level, and formed a chain of islands in the Central Paratethys. Due to the position of these islands and the lack of terrigenous influx, coral growth was prolific (RIEGL \& PILler 2000; SCHMid et al. 2001).

The Hummel section is up to $15 \mathrm{~m}$ high and more than $60 \mathrm{~m}$ long, it was originally built as an access for a private railway into the Hummel limestone quarry. The Hummel quarry also exposes Badenian Leitha Limestone, which formed a palaeorelief during the Sarmatian (a regional equivalent of the Upper Serravallian; Harzhauser \& PILler 2010). The W-E trending railway cut exposes deposits, documenting a perfect cross-section of a Sarmatian rocky coast which was formed by the already lithified Badenian corallinacean limestones. For further data regarding the geology of the Hummel railway cut see HARZHAUSER \& Piller (2004).

Since a large percent of the St. Margarethen fish remains of the HNHM collection is embedded in characteristic pieces of laminated marly or corallinacean Leitha Limestone (Badenian in age), following parsimony here I consequently refer the same age for the whole material, including fully prepared and cleaned specimens, until further results (e.g. geochemical investigations) lead to a different conclusion. Note that the so-called "fish-bearing" laminated marl facies of the Leitha Limestone (from where some St. Margarethen articulated bony fishes of the HNHM collection most possibly originate) crops out in the Kummer quarry (SCHMID et al. 2001), and the Roman and Kummer quarries are more popular among both palaeontologists and private fossil collectors, therefore the St. Margarethen material of the HNHM collection likely originates from one of these sites. 


\section{MATERIAL AND METHODS}

All studied specimens are housed in the Hungarian Natural History Museum (Budapest). In some cases, remains of different taxa have been inventoried under the same inventory number. For simplified data of inventory, see Appendix.

The fish fossils are in excellent condition. Most shark teeth are with root preserved, the crown enamel is greyish-bluish in colour, while ray teeth and the bony fish fossil teeth are with yellowish-greyish, sometimes brownish colouration. The fossils were cleaned with brushes using tap water, broken specimens were fixed with cyanoacrylate adhesive (superglue). No mechanical preparation was carried out. For scanning electron microscopic photography, a Hitachi S-2600N scanning electron microscope was used.

Chondrichthyan taxonomy follows CAPpetTa (2012), while that of osteichthyans follows Nelson et al. (2016). Descriptive tooth terminology of chondrichthyans follows CAPPETTA (2012), Bor et al. (2012), and REINECKE et al. $(2011,2014)$.

\section{SYSTEMATIC PALAEONTOLOGY}

Class Chondrichthyes Huxley, 1880

Superorder Selachimorpha Nelson, 1984

Order Lamniformes Berg, 1937

Family Odontaspididae Müller et Henle, 1839

Genus Araloselachus Glikman, 1964

Araloselachus vorax (Le Hon, 1871)

(Figs 4-12)

Referred material - 12 teeth (V.61.915, V.61.917, V.61.921, V.62.396, V.63.412, V.69.1059, V.69.1100).

Description - The main cusp of anterior files is slender and pointed, showing a slight lingual curvature in profile view (Figs 4-9). Upper lateral tooth (V.62.396) has distally inclined main cusp, straight in profile view (Figs 10-12). While the examined anterior teeth are $\times 1.5-2$ higher apicobasally than wide mesiodistally, the upper lateral tooth is nearly as wide as high. The cutting edge of all teeth is smooth and sharp, it runs from the tip to the crown-base. The labial crown face is weakly convex to flat, while the labial is strongly convex. The enameloid surface of the labial crown face is completely smooth. The root is bilobate, the lobes meet in a pronounced lingual protuberance, bearing a large nutrient groove. The lobes bear usually two pairs of sharp cusplets (some anterior files bear only one pair), of which the first pair is strongly hooked towards the main cusp in anterior teeth. 
Remarks - This species was originally described as Lamna (Odontaspis) vorax by LE HON (1871). Later on, it was widely included in Carcharias (e.g. DE SCHUTter 2011; see also synonym lists of REINECKE et al. 2011 and Bor et al. 2012), but Bor et al. (2012) re-assigned the species into the genus Araloselachus.

From the Miocene of Europe, large-sized odontaspidid teeth with smooth labial crown face are widely referred to as Araloselachus cuspidatus and $A$. vorax (e.g. REINECKE et al. 2011, 2014). The two species seem to be closely related, but the latter species has smaller, less-massive teeth, also less-developed root lobes, with multiple pairs of sharp and hooked lateral cusplets, of which the secondary ones are well developed, especially in anterior files (see De SCHUTtER 2011; REINECKE et al. 2011; Bor et al. 2012: 23). A. vorax is distributed mainly in the North Sea Basin during the Burdigalian-Tortonian, but it seems to occur occasionally in the Burdigalian-Langhian deposits of the Central Paratethys exposed in Austria and southern Germany (De Schutter 2011: 179).

Teeth of C.acutissima and C. taurus, two hardly distinguishable species widespread in the Badenian of the Central Paratethys, are easily separable from $A$. vo-

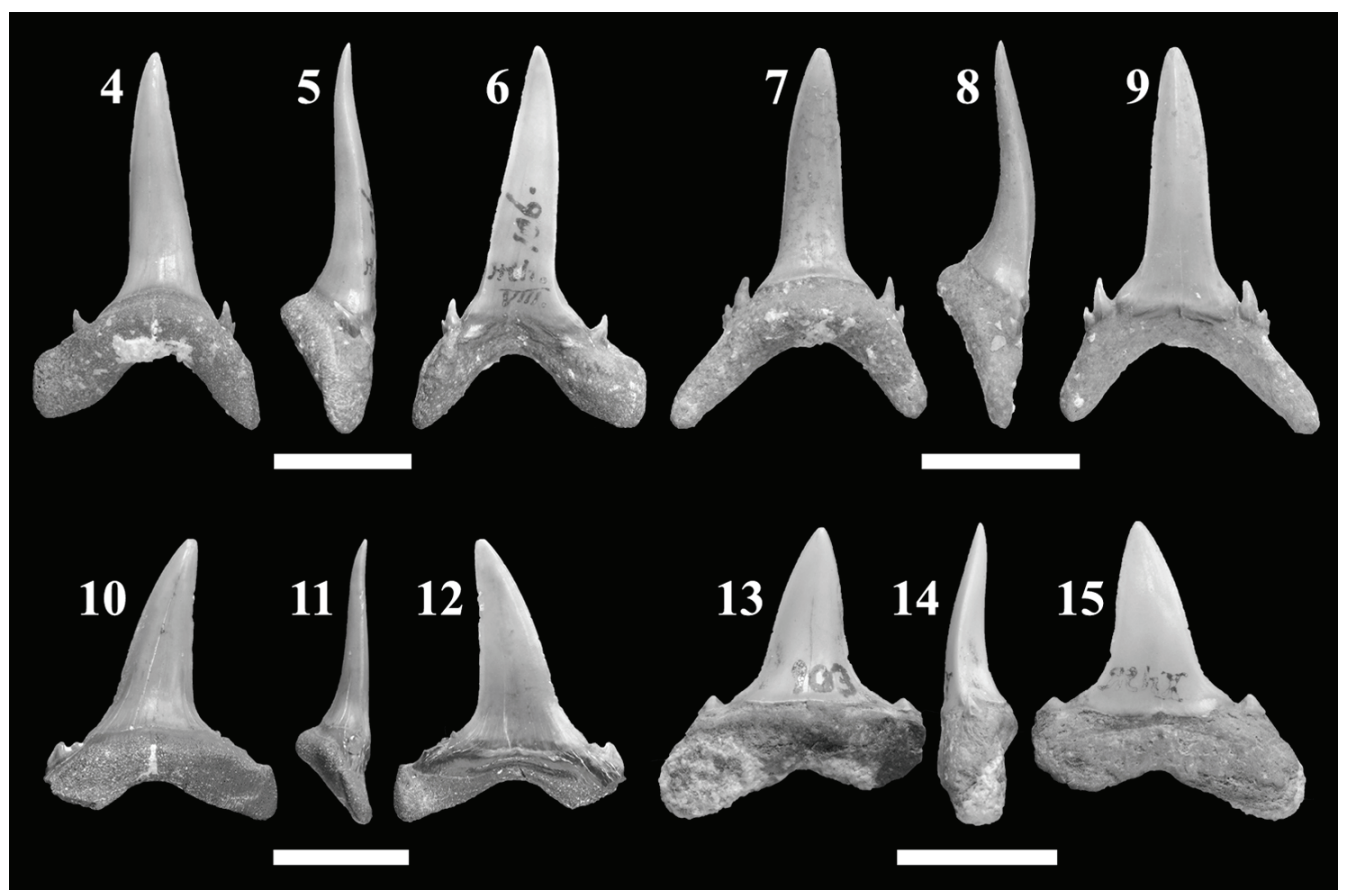

Figs 4-12. Araloselachus vorax (Le Hon, 1871). - Figs 4-6. Anterior tooth, V.69.1059. - Fig. 4. Lingual view. - Fig. 5. Mesial view. - Fig. 6. Labial view. - Figs 7-9. Anterior tooth, V.61.915. Fig. 7. Lingual view. - Fig. 8. Mesial view. - Fig. 9. Labial view. - Figs 10-12. Upper lateral tooth, V.62.396. - Fig. 10. Lingual view. - Fig. 11. Distal view. - Fig. 12. Labial view. - Figs 13-15. cf. Carcharias crassidens (Agassiz, 1838), V.69.1092. - Fig. 13. Lingual view. - Fig. 14. Profile view. -

Fig. 15. Labial view. Scale bars: $10 \mathrm{~mm}$ 
rax, as they have slender teeth with apicobasally striated lingual crown face (WARD \& Bonavia 2001; REINECKE et al. 2011, 2014; SzABó \& Kocsis 2016, table 2).

\author{
Family Carchariidae Müller et Henle, 1841 \\ Genus Carcharias Rafinesque, 1810 \\ cf. Carcharias crassidens (Agassiz, 1838)
}

(Figs 13-15)

Referred material - 1 tooth (V.69.1092).

Description - The single here referred tooth is nearly as wide mesiodistally as high apicobasally. The main cusp is upright, triangular, and narrow in labial and lingual views (Fig. 13), with a flattened labial and convex lingual face. Both faces and cutting edges are smooth, the cutting edges reach the crown base, and continue on the lateral cusplets. The main cusp has a weak lingual inclination in profile view (Fig. 14). The root is bilobate, the lobes are well separated, of which the better preserved one has a rounded extremity. The lobes meet in an obtuse angle. Both lobes bear one lateral cusplet, fused to the basal edges of the main cusp. The labial root face bears a characteristic, mesiodistally running ridge below the crown base (Fig. 15).

Remarks - Here I follow STONE \& SHIMADA (2019), who resurrected family Carchariidae for the genus Carcharias to separate it from family Odontaspididae. Tooth V.69.1092 is reminiscent of a figured type specimen of Carcharias crassidens (= Lamna crassidens, see AGAssiz 1838, pl. 35, fig. 11, 11'). Since the validity of this species is doubtful, and its general tooth morphology is similar to that of the genus Araloselachus, here I refer tooth V.69.1092 provisionally as cf. Carcharias crassidens, until a revision of $C$. crassidens is done, or further specimens from St. Margarethen are identified.

\title{
Carchariidae indet. or Odontaspididae indet.
}

(Figs 16-65)

Referred material - a slightly disarticulated, partial dentition surrounded by placoid scales and suggested portions of cartilage (VER 2020.69.1.), from which 15 placoid scales (VER 2020.70.1.-84.1.), 1 piece of stone matrix embedding at least 5 placoid scales (VER 2020.85.1.), and 6 pieces of suggested cartilage tissue (VER 2020.86.1.-90.1.) were isolated.

Description - Based on the visible crown portions, specimen VER 2020.69.1. (Fig. 16) consists of at least 32 teeth, however, it is hard to tell how many teeth the broken root portions belong to. Some teeth are preserved in labial, while some in lingual aspect. The teeth represent the upper and lower anterior and lateral files, in- 
cluding the intermediate file of the upper dentition (Figs 17-25). No posterior files are visible. All teeth which are embedded in lingual aspect, possess a smooth lingual crown face. Based on the variety of the observed tooth positions, VER 2020.69.1. represents a slightly disarticulated mixture of the upper and lower dentition.

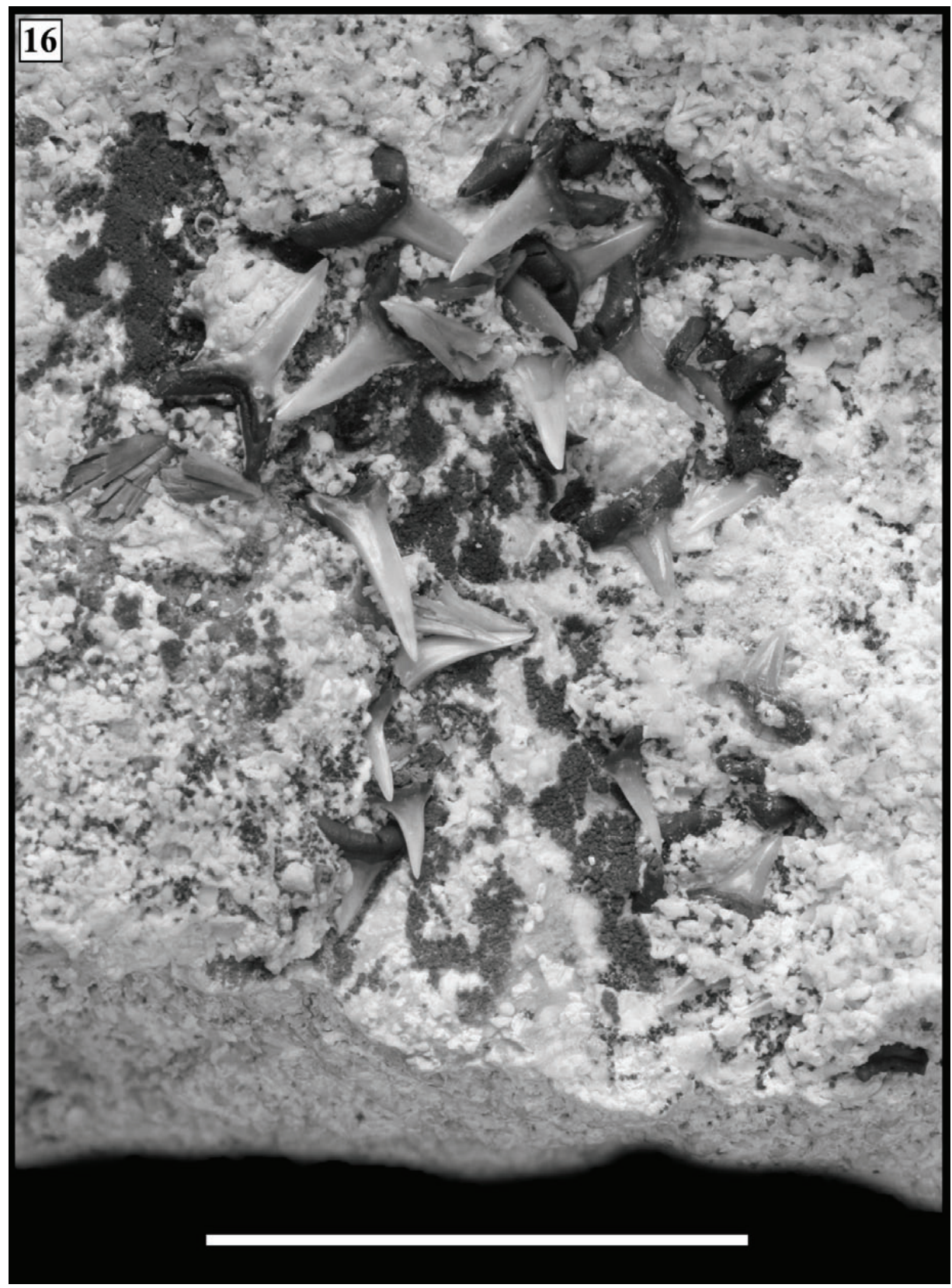

Fig. 16. Carchariidae indet. or Odontaspididae indet. partial dentition, VER 2020.69.1. Scale bar: $20 \mathrm{~mm}$ 


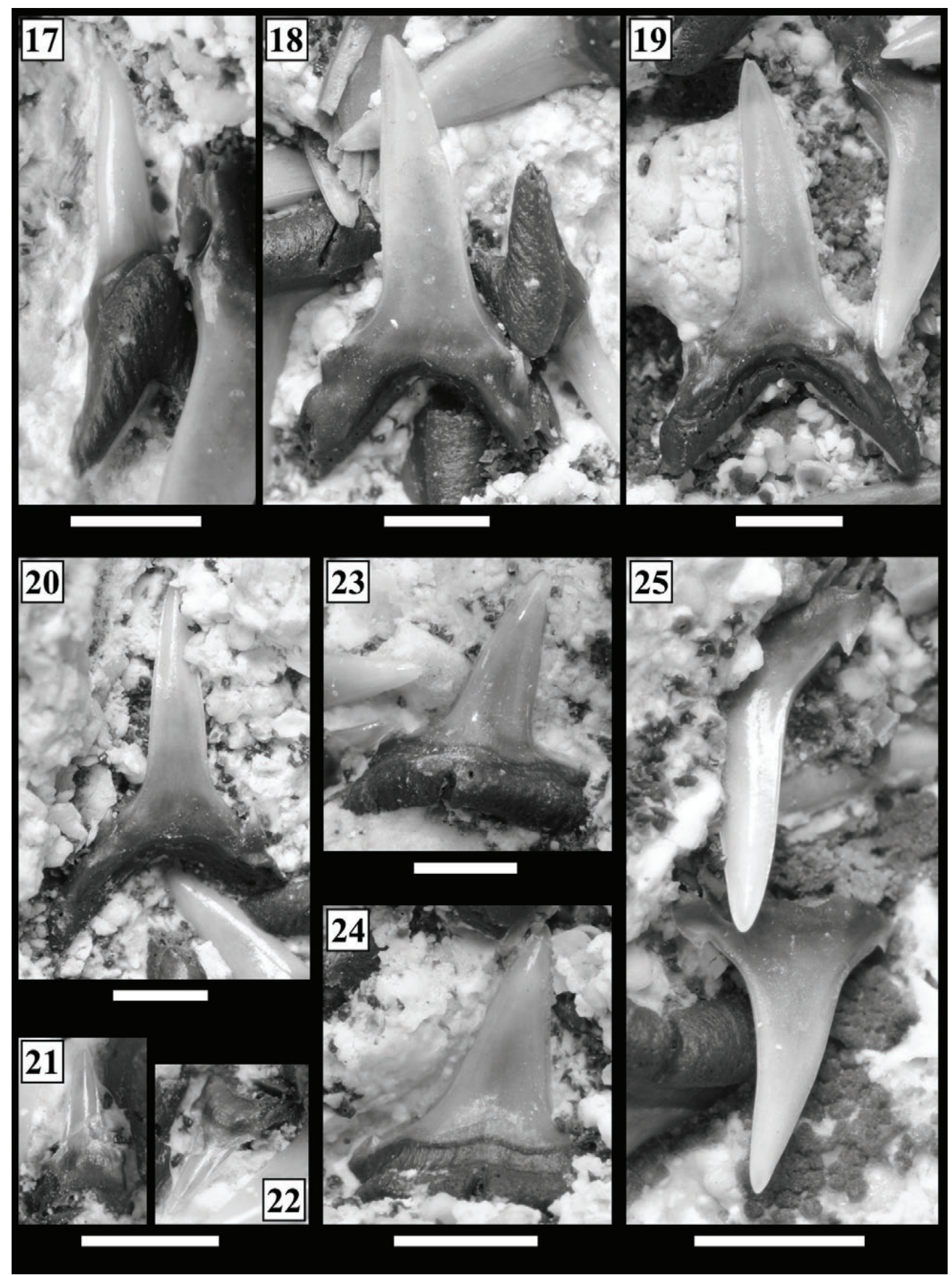

Figs. 17-25. Teeth in specimen VER 2020.69.1. - Fig. 17. Lower anterior (parasymphyseal) tooth in lingual aspect. - Fig. 18. ?Upper anterior tooth in labial aspect. - Fig. 19. ?Lower anterior tooth in labial aspect. - Fig. 20. ?Upper anterior tooth in labial aspect. - Figs 21-22. Upper intermediate tooth in labial aspect. - Fig. 23. Upper lateral tooth in lingual aspect. - Fig. 24. Upper lateral tooth in lingual aspect. - Fig. 25. Lower lateral teeth in labial aspect. Scale bars: $2 \mathrm{~mm}$ 
A large number of placoid scales are visible in the embedding limestone matrix. Placoid scales were isolated from three areas around the dentition, where the scales are densely aggregated (Fig. 26). It is noteworthy that placoid scales sparsely occur over a large part of the surface of the embedding piece of limestone. The isolated placoid scales represent four morphotypes. Morphotype 1 (isolated from areas I and III; see Figs 27-36, 49, 50) has drop- or arrowhead-shaped crown. Threefour anteriorly bulging, parallel folds are present on the apical surface, reaching from the anterior margin to the anteroposterior half of the crown. The crown of placoid scales representing Morphotype 2 (isolated from area II; see Figs 37-46) is circular in apical view. The anterior margin is weakly folded. Morphotype 3 (isolated from area III; see Figs 47, 48, 51-56) is similar to Morphotype 1 in having a pointed posterior edge, but the crown meets the base in a lower angle. This morphogroup seems to represent an intermediate form between the first and the fourth morphotype. Morphotype 4 (isolated from area III; see Figs 57, 58) has tricuspid crown, bearing an anteriorly bulging median keel, laterally flanked by parallel folds. The lateral folds diminish posteriorly, while the median keel reaches the posterior margin of the crown. The base of all morphotypes bears large foramina.

The suggested cartilage tissue of specimen VER 2020.69.1. is built up of mosaically adjacent units of irregular outline. The largest, and also the most wellpreserved portions of the suggested cartilage are between the surface area I and III (Figs 59-61). Pieces of this structure were also isolated for scanning electron microscopic photography (Figs 62-65).

Remarks - Based on genetic studies, STONE \& SHIMADA (2019) resurrected Carchariidae for genus Carcharias to separate it from family Odontaspididae. However, tooth morphology of the here referred fossil taxa was a subject of many

Fig. 26. Areas I-III of specimen VER 2020.69.1. from where placoid scales were isolated. Figs 27-28. VER 2020.70.1. - Fig. 27. Apical view. - Fig. 28. Profile view. - Figs 29-30. VER 2020.71.1. - Fig. 29. Apical view. - Fig. 30. Profile view. - Figs 31-32. VER 2020.72.1. - Fig. 31. Apical view. - Fig. 32. Profile view. - Figs 33-34. VER 2020.73.1. - Fig. 33. Apical view. - Fig. 34. Profile view. - Figs 35-36. VER 2020.74.1. - Fig. 35. Apical view. - Fig. 36. Profile view. Figs 37-38. VER 2020.75.1. - Fig. 37. Apical view. - Fig. 38. Profile view. - Figs 39-40. VER 2020.76.1. - Fig. 39. Apical view. - Fig. 40. Profile view. - Figs 41-42. VER 2020.77.1. - Fig. 41. Apical view. - Fig. 42. Profile view. - Figs 43-44. VER 2020.78.1. - Fig. 43. Apical view. - Fig. 44. Profile view. - Figs 45-46. VER 2020.79.1. - Fig. 45. Apical view. - Fig. 46. Profile view. - Figs 47-48. VER 2020.80.1. - Figs 49-50. VER 2020.81.1. - Fig. 49. Apical view. - Fig. 50. Profile view. - Figs 51-52. VER 2020.82.1. - Fig. 51. Apical view. - Fig. 52. Profile view. - Figs 53-54. VER 2020.83.1. - Fig. 53. Apical view. - Fig. 54. Profile view. - Figs 55-56. VER 2020.84.1. - Fig. 55. Apical view. - Fig. 56. Profile view. - Figs 57-58. VER 2020.85.1. - Fig. 57. Apical view. - Fig. 58. Profile view. Placoid scales of Morphotype 1: Figs 27-36, 49, 50; Morphotype 2: Figs 37-46; Morphotype 3: Figs 47, 48, 51-56; Morphotype 4: Figs 57, 58. Scale bars: 26: $5 \mathrm{~cm}$; 27-46, 49-58: 
studies in the past (e.g. De SCHUtTer 2011; ReINECKe et al. 2011, 2014; Bor et al. 2012; CAPPETTA 2012), and differential tooth characteristics of the two families have not been detailed since the work of STONE \& SHIMAdA (2019). Except

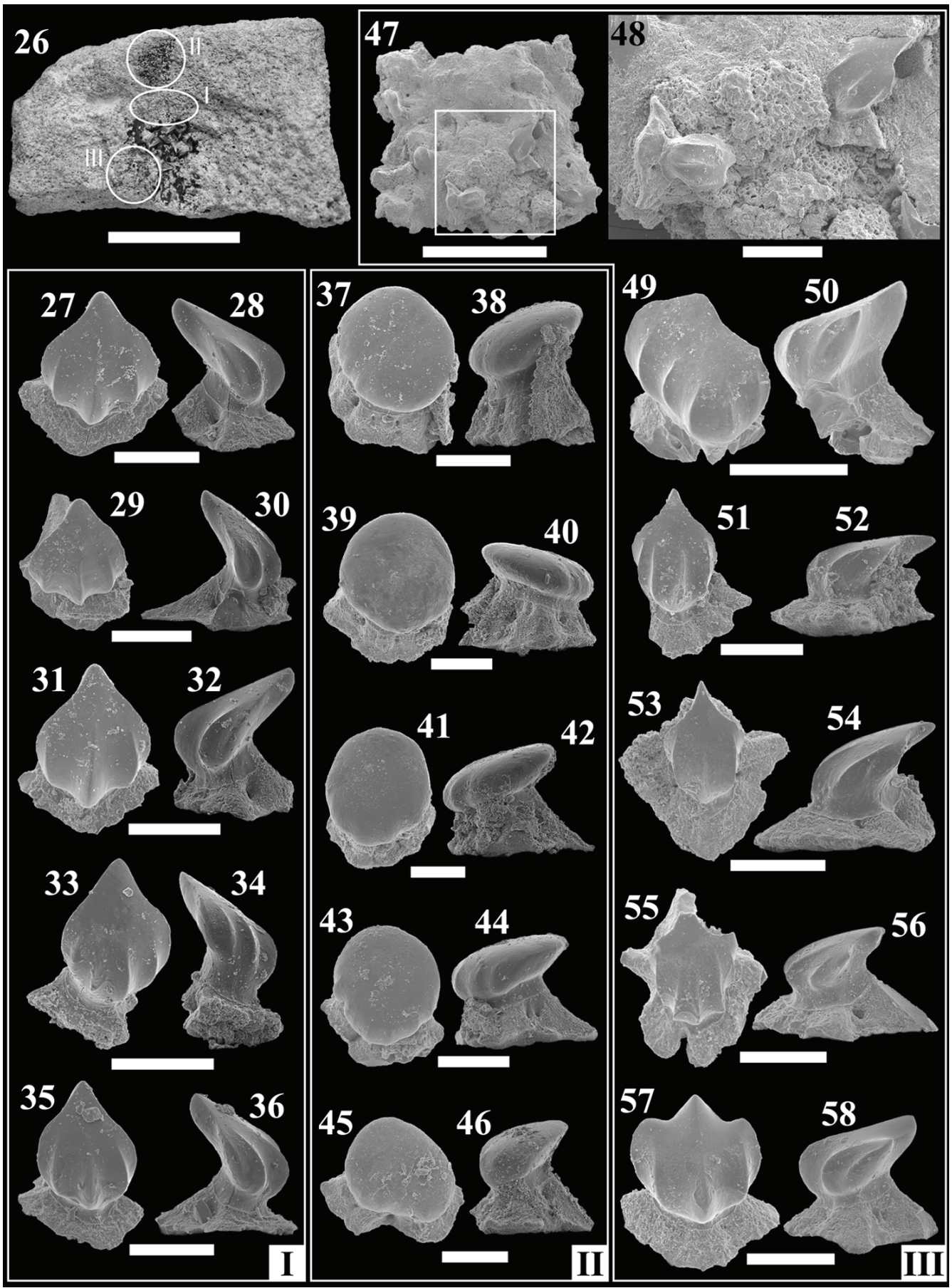


for the less-developed and low number of lateral cusplets (usually one pair in any teeth of specimen VER 2020.69.1.), the dental characteristics are comparable with those of $A$. vorax (see De Schutter 2011; Bor et al. 2012). The notably small size of the teeth refers specimen VER 2020.69.1. (and its isolated portions) to a juvenile individual, with assumedly less-developed dental characteristics. However, two different shark species sharing similar dental characteristics, while inhabiting the same environment is highly unlikely from the biological point of view (after REINECKE et al. 2011:21), following its ontogenetic stage, an assignment of specimen VER 2020.69.1. (and its isolated portions) to $A$. vorax would be quite hazardous. As both Carchariidae and Odontaspididae are reported from St. Margarethen (SCHMID et al. 2001; present study), here I find more appropri-

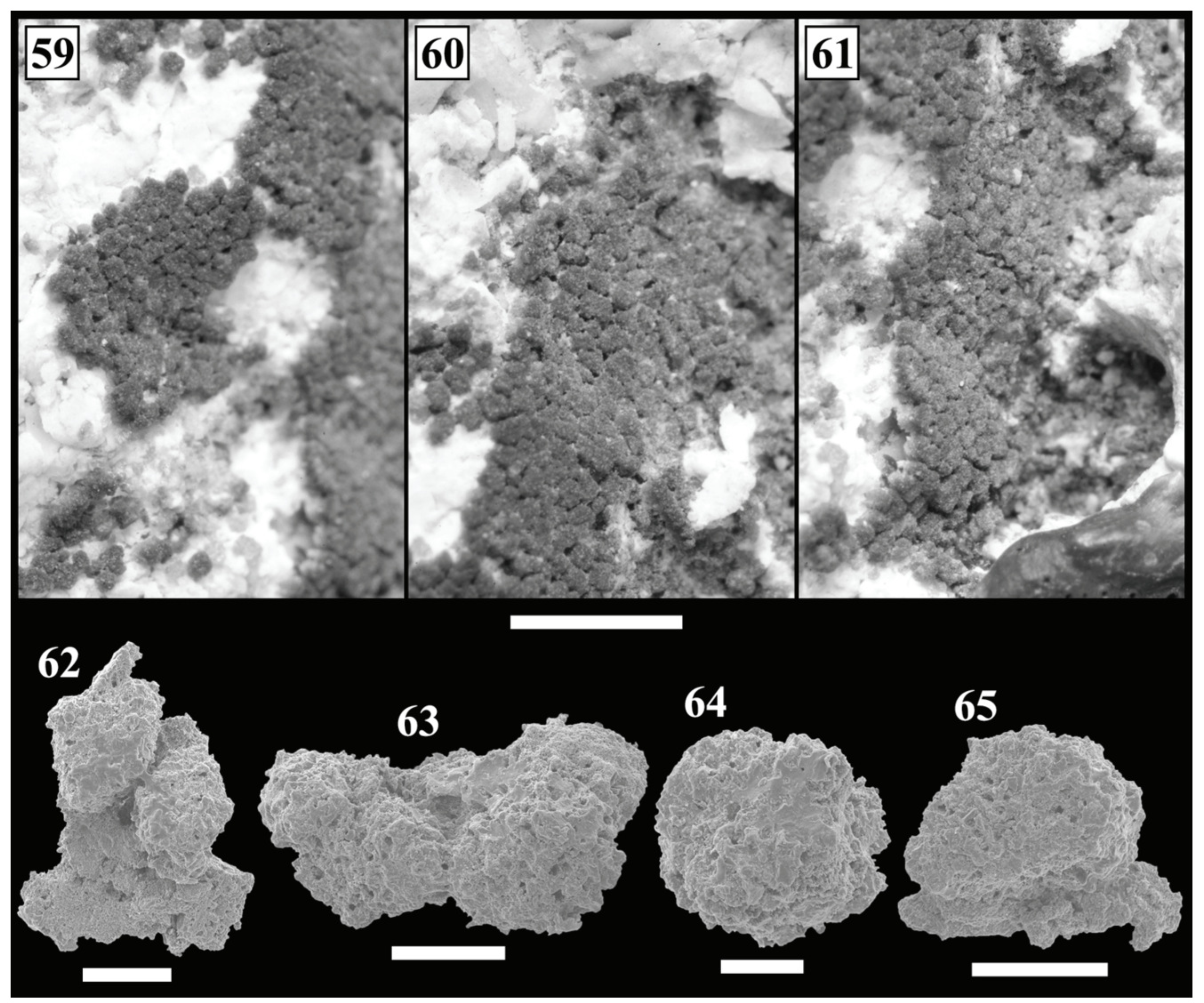

Figs 59-61. Close-up of VER 2020.69.1. between areas I and III, where large portions of the suggested fossilized cartilage tissue is exposed. - Figs 62-65. Scanning electron microscopic pictures of isolated pieces of the suggested fossilized cartilage tissue. - Fig. 62. VER 2020.86.1. - Fig. 63. VER 2020.88.1. - Fig. 64. VER 2020.89.1. - Fig. 65. VER 2020.90.1. Scale bars: 59-61: 2 mm; 62, 63: $200 \mu \mathrm{m} ; 64: 100 \mu \mathrm{m} ; 65: 250 \mu \mathrm{m}$ 
ate to describe specimen VER 2020.69.1. with all of its isolated portions only as Carchariidae indet. or Odontaspididae indet. Differences in tooth morphology of these two, hardly separable families are not detailed yet, which is beyond the scope of the present study.

It is worth mentioning that placoid scales of Morphotype 2 are weakly reminiscent of scales/those of an embrional individual of the Oligocene-Miocene species C. gustrowensis (Hovestadt \& Hovestadt-Euler 2010, fig. 6. 68.), in having a circular, anteriorly folded crown. REIF (1985) figured dermal denticles of the extant species Carcharias taurus, but they have a different morphology by having much stronger folds on the apical surface, reaching the posterior edge of the denticles.

Family Lamnidae Müller et Henle, 1838

Genus Cosmopolitodus Glikman, 1964

Cosmopolitodus hastalis (Agassiz, 1838)

(Figs 66-71)

Referred material - 13 teeth (V.61.917, V.61.925, V.61.1278, V.61.1280, V.62.395, V.62.397, V.62.399, V.69.286, V.69.306, V.69.1010, V.69.1038, V.69.1092).

Description - The crown of upper anterior and anterolateral teeth (Figs 66, 67 ) is high, triangular and labiolingually flattened. The labial crown face is flat, while the lingual is weakly convex. Upper lateral teeth have a distally directed crown, rapidly widening basally, extending onto the shoulders of the root lobes, and sometimes forming a heel in upper distal files (see V.62.399, Figs 68, 69). The short root lobes of upper files are weakly pronounced lingual protuberance. Lower teeth (Figs 70,71) have lingually weakly curved, narrow crown (compared to upper teeth), the labial crown face is weakly, while the lingual is strongly convex. The root of lower files is built up of well-separating lobes. The crown faces and cutting edges of all files are smooth. The lingual crown-root boundary is marked by a narrow dental band in all files.

Remarks - This species is widespread in the Badenian deposits of the Central Paratethys (SzABó \& Kocsis 2016, table 2). Following the dental similarities of Cosmopolitodus and Carcharodon carcharias, some authors place the species into the genus Carcharodon (e.g. EHret et al. 2012; Trif \& Codrea 2017; Kent in Godfrey 2018; MAISCH et al. 2018). Since the evolutional relationship of Cosmopolitodus and Carcharodon is not fully resolved at present, here I follow CAPPETTA (2012), who places species hastalis in genus Cosmopolitodus. 


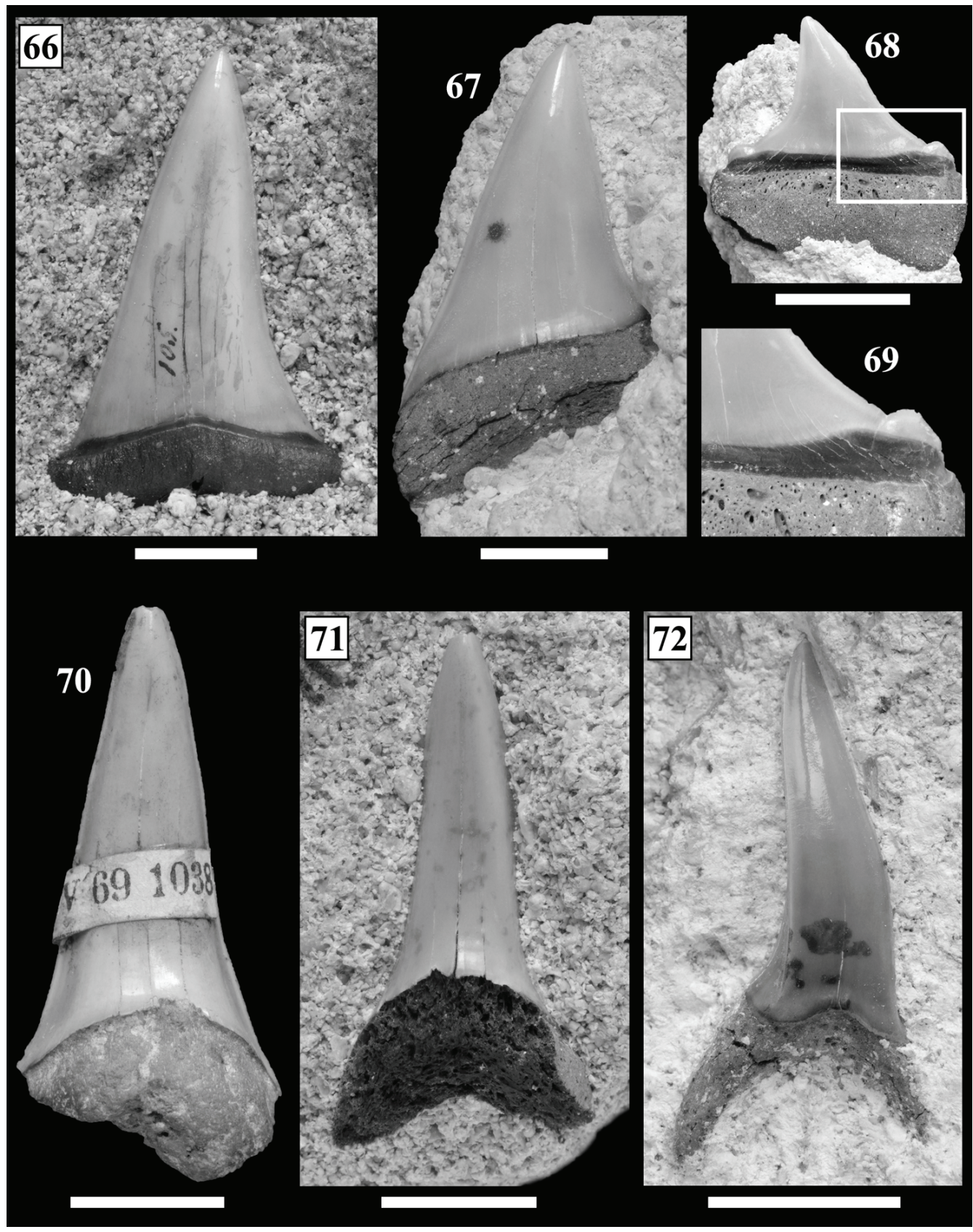

Figs 66-71. Cosmopolitodus hastalis (Agassiz, 1838). - Fig. 66. Upper anterior tooth, V.69.1010, lingual view. - Fig. 67. Upper anterolateral tooth, V.61.1280, lingual view. - Figs 68-69. Upper lateral tooth, V.62.399. - Fig. 68. Labial view. - Fig. 69. Close-up of the mesial crown edge of the same specimen. - Fig. 70. Lower anterior tooth, V.69.1038, lingual view. - Fig. 71. Lower anterior tooth, V.69.306, lingual view. - Fig. 72. Isurus oxyrinchus (Agassiz, 1843), ?lower anterior tooth, V.61.915, labial view. Scale bars: $10 \mathrm{~mm}$ 
Genus Isurus Rafinesque, 1810

Isurus oxyrinchus (Agassiz, 1843)

(Fig. 72)

Referred material - 1 tooth (V.61.915).

Description - The only tooth referred here is embedded in a piece of Leitha Limestone, in labial aspect (Fig. 72). The crown is slender and pointed, it slightly inclines distally, with a lingual curvature the very tip reclines labially. Both cutting edges are smooth, the mesial is convex, while the distal is nearly straight. The distal cutting edge does not reach the crown base. The root is bilobate and slightly asymmetrical, the lobes meet in an acute angle. Based on the preserved dental characteristics, specimen V.61.915 is referred as an anterior tooth, most likely from the lower dentition (REINECKE et al.2011, pl. 40 with all figurations; CAPpetTa 2012, fig. 203H, I).

Remarks - PURDY et al. (2001) noted that $I$. desori should be considered as junior synonym of I. oxyrinchus. Bor et al. (2012: 34) also suggest that there is no sufficient difference between Miocene teeth of the "desori" morphotype and teeth of extant I. oxyrinchus, which would support handling them under separate names. When treating the two species as synonyms, it can be concluded that I. oxyrinchus was widely distributed in the Central Paratethys during the Early and Middle Miocene (RAdWAŃs Ki 1965; SCHUltz 1971; Holec et al. 1995; Kocsis 2007).

\title{
Lamnidae indet.
}

Referred material - 9 teeth (V.61.914, V.61.924, V.61.927, V.61.928, V.62.397, V.62.402, V.63.412, V.69.1057, V.69.1092).

Description - A few rootless and/or broken crowns and incomplete root remains, similar to those of $C$. hastalis and I. oxyrinchus are referred here. However, due to their poor preservation their assignment to any lamnid at St. Margarethen would be uncertain.

\author{
Family Otodontidae Glikman, 1964 \\ Genus Otodus Agassiz, 1838 \\ Subgenus Megaselachus Glikman, 1964 \\ Otodus (Megaselachus) megalodon (Agassiz, 1835)
}

(Figs 73-78)

Referred material - 8 teeth(V.60.1741, V.61.940, V.61.944, V.61.1278, V.61.1282).

Description - The teeth are large and massive. The crown is triangular, both crown faces are smooth. The labial crown face is flat, while the lingual is convex. 


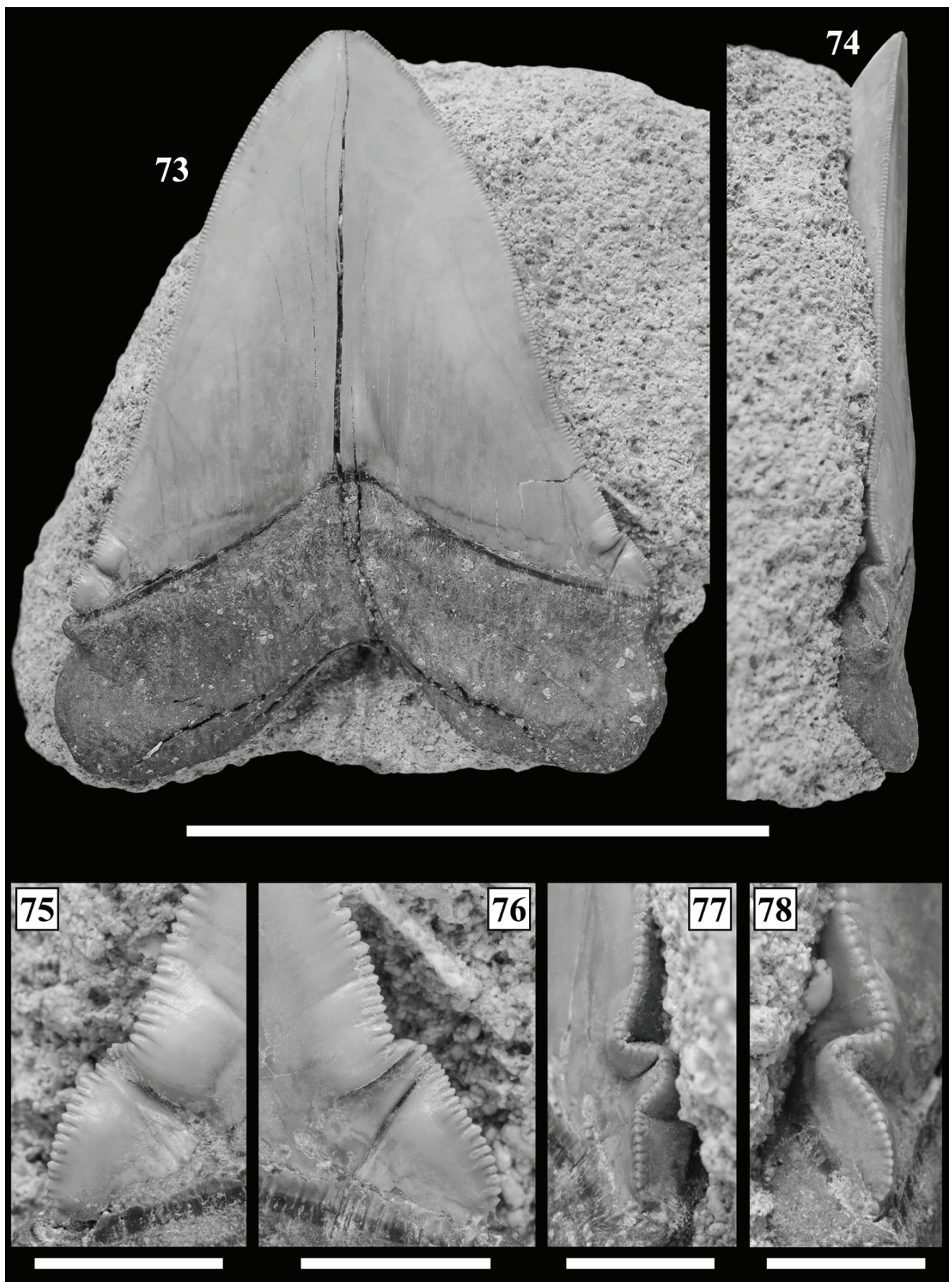

Figs 73-78. Otodus (Megaselachus) megalodon (Agassiz, 1835), upper anterior tooth, V.60.1741. Fig. 73. Labial view. - Fig. 74. Profile view. - Figs 75-78. Close-up of the mesial and distal crown bases, showing the pathological deformity. - Figs 75-76. Labial view. - Figs 77-78. Profile view. Scale bars: Figs 73-74: $10 \mathrm{~cm}$; Figs 75-78: $10 \mathrm{~mm}$ 
Both cutting edges bear strong, regular serrations. The root-crown junction bears a well-developed and high, V-shaped chevron (= "neck") on the lingual crown face. The root is bilobate, the lobes are equal in size. The most complete specimen (V.60.1741) is embedded in a piece of limestone in labial aspect (Figs 73, 74). This tooth shows a pathological deformity: the distal and mesial cutting edge undulates at the crown base (Figs 75-78).

Remarks - Here I follow the system of CAPPETTA (2012), however, his division of Otodus into subgenera Otodus, Carcharocles, and Megaselachus is not further supported by some authors (e.g. Bor et al. 2012). Otodus (Megaselachus) megalodon is the largest macropredatory shark ever lived. It was previously reported from St. Margarethen by Schmid et al. (2001). The species is widely known from the Badenian of the Central Paratethys (Sza Bó \& Kocsis 2016, table 2). Schultz (1971, pl.3, fig 17a, b) figures a tooth of Otodus (Megaselachus) megalodon with a pathological deformity similar to that of specimen V 60.1741.

\section{Order Carcharhiniformes Compagno, 1973 \\ Family Hemigaleidae Hasse, 1879 \\ Genus Hemipristis Agassiz, 1835 \\ Hemipristis serra Agassiz, 1835}

(Figs 79, 80)

Referred material - 3 teeth (V.61.937, V.62.405, V.63.480).

Description - Specimens V.61.937 and V.62.405 are embedded in a piece of limestone matrix in labial aspect (Figs 79, 80). All of the here referred teeth have similar morphology. The crown is triangular, and distally inclined. Both cutting edges are coarsely serrated. The root is bilobate, the lobes are well-separated, with angled extremities. This morphology refers the teeth as upper files.

Remarks - The species is also widely reported from the Badenian deposits of the Central Paratethys (SzABó \& Kocsis 2016, table 2). The genus is represented by a single extant species $H$. elongata, distributed in the Indo-West Pacific (EBERT et al. 2013).

Family Carcharhinidae Jordan et Evermann, 1896

Genus Galeocerdo Müller et Henle, 1838

Galeocerdo aduncus (Agassiz, 1835)

(Figs 81-85)

Referred material - 8 teeth (V.61.924, V.61.1281, V.69.1066, V.69.1089, V.69.1096). 
Description - Both faces of the crown are smooth, the labial one is flat, while the lingual is convex. The convex mesial cutting edge bears slightly irregular serrations varying between fine and uniform. The straight to weakly convex distal cutting edge is shorter than the mesial edge, and finely serrated. A distal crown heel is present, which is separated from the distal cutting edge by a deep notch. The heel is convex in labial (and lingual) view, it declines to the distal crown margin. The root is apicobasally low and mesiodistally wide, the root lobes meet in an obtuse angle forming a weak lingual protuberance.

Remarks - This extinct tiger shark species is widely reported from the Badenian of the Central Paratethys (Szabó \& Kocsis 2016, table 2).

Genus Carcharhinus Blainville, 1816

Carcharhinus priscus (Agassiz, 1843)

(Figs 86-89)

Referred material - 8 teeth (V.61.916, V.61.934, V.61.941, V.61.1279, V.63.482, V.63.483, V.69.883).

Description - A strong dignathic heterodonty is characteristic for the species. Upper teeth (Figs 86, 87) have triangular, labiolingually flattened crown with flat labial, and weakly convex lingual face. The cutting edges are serrated, they continue to the root lobes, forming serrated heels both mesially and distally. The root is mesiodistally wide, the lobes meet in an obtuse angle. Lower teeth (Figs 88, 89) have slender, upright cusp. The cutting edges and the heels are entire and smooth. The root is laterally expanded, the lobes are symmetrical with rounded extremities. The lingual protuberance bears a nutrient groove in all files.

Remarks - C.priscus is also widely reported from the Badenian of the Central Paratethys (SzA Bó \& Kocsis 2016, table 2). This species has likely evolved from the Early Oligocene C. elongatus or the Late Oligocene C.gibbesi (Bor et al. 2012, and references therein).

Carcharhinidae indet.

(Figs 90, 91)

Referred material - 1 vertebra (V.63.478).

Description - A single centrum, showing diagnostic features of those of Carcharhinidae (Kozuch \& Fitzgerald 1989) is discussed here. Some portions around the edges are missing, the overall surface seems to be a bit eroded, and therefore no pores are visible on the sides. The concave articular surface shows circular annuli (Fig. 90). The dorsal foramina are oval, they do not extend the rims of the centrum (Fig. 91). 


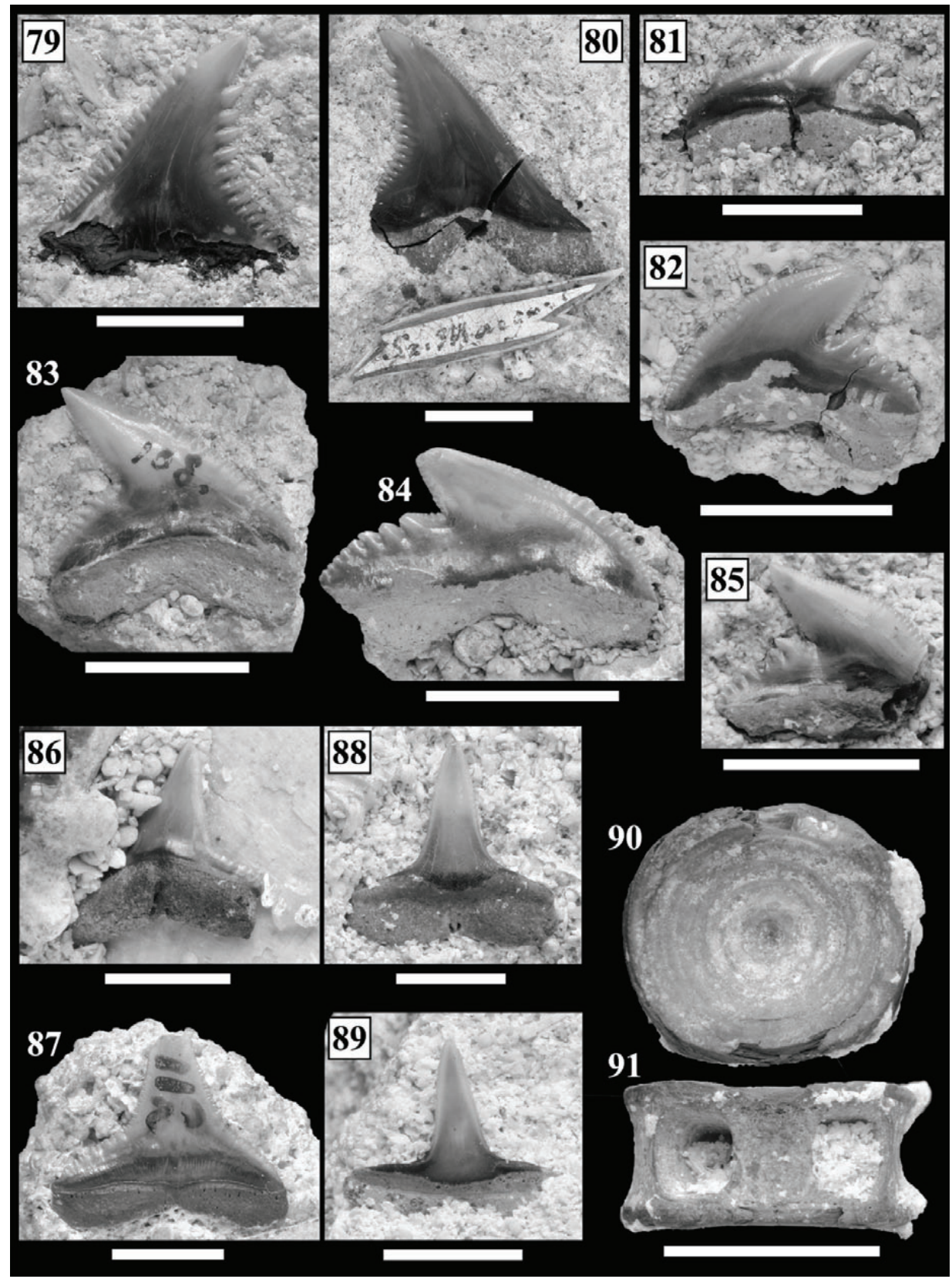

Figs 79-80. Hemipristis serra Agassiz, 1835. - Fig. 79. Upper tooth, V.62.405, labial view. - Fig. 80. Upper tooth, V.61.937, labial view. - Figs 81-85. Galeocerdo aduncus (Agassiz, 1835). - Figs 81-82. V.61.924. - Fig. 81. Lingual view. - Fig. 82. Labial view. - Fig. 83. V.69.1096, labial view. Fig. 84. V.61.924, labial view. - Fig. 85. V.69.1096, labial view. - Figs 86-89. Carcharhinus priscus (Agassiz, 1843). - Fig. 86. Upper tooth, V.61.1279, lingual view. - Fig. 87. Upper tooth, V.69.883, labial view. - Fig. 88. Lower tooth, V.61.926, labial view. - Fig. 89. Lower tooth, V.61.941, labial view. - Figs 90-91. Carcharhinidae indet., vertebra, V.63.478. - Fig. 90. Articular view. - Fig. 91.

Dorsal view. Scale bars: Figs 79-85, 90-91: $10 \mathrm{~mm}$; Figs 86-89: $5 \mathrm{~mm}$ 
Remarks - Similar carcharhinid centra have been reported by PURDY et al. (2001, fig. 52e, f), Bor et al. (2012, pl. 57, figs 1, 2, 6), SzABó et al. (2017, fig. 8kn) and SzA вó \& Kocsis (2020, pl. 10, figs 1-12). Due to the lack of characters, it is undefinable, whether this centrum belongs to G. aduncus or C. priscus, and it is identified here only as Carcharhinidae indet.

Order Myliobatiformes Compagno, 1973

Family Myliobatidae Bonaparte, 1838

Genus Aetobatus Blainville, 1816

Aetobatus arcuatus (Agassiz, 1843)

(Figs 92-95)

Referred material - 10 teeth (V.61.913, V.61.936, V.63.671).

Description - Only lower teeth are known in the HNHM collection. Lower teeth of $A$. arcuatus are of crescent shape, with distally curved lateral edges. The crown is low and straight with smooth occlusal surface. The crown is separated

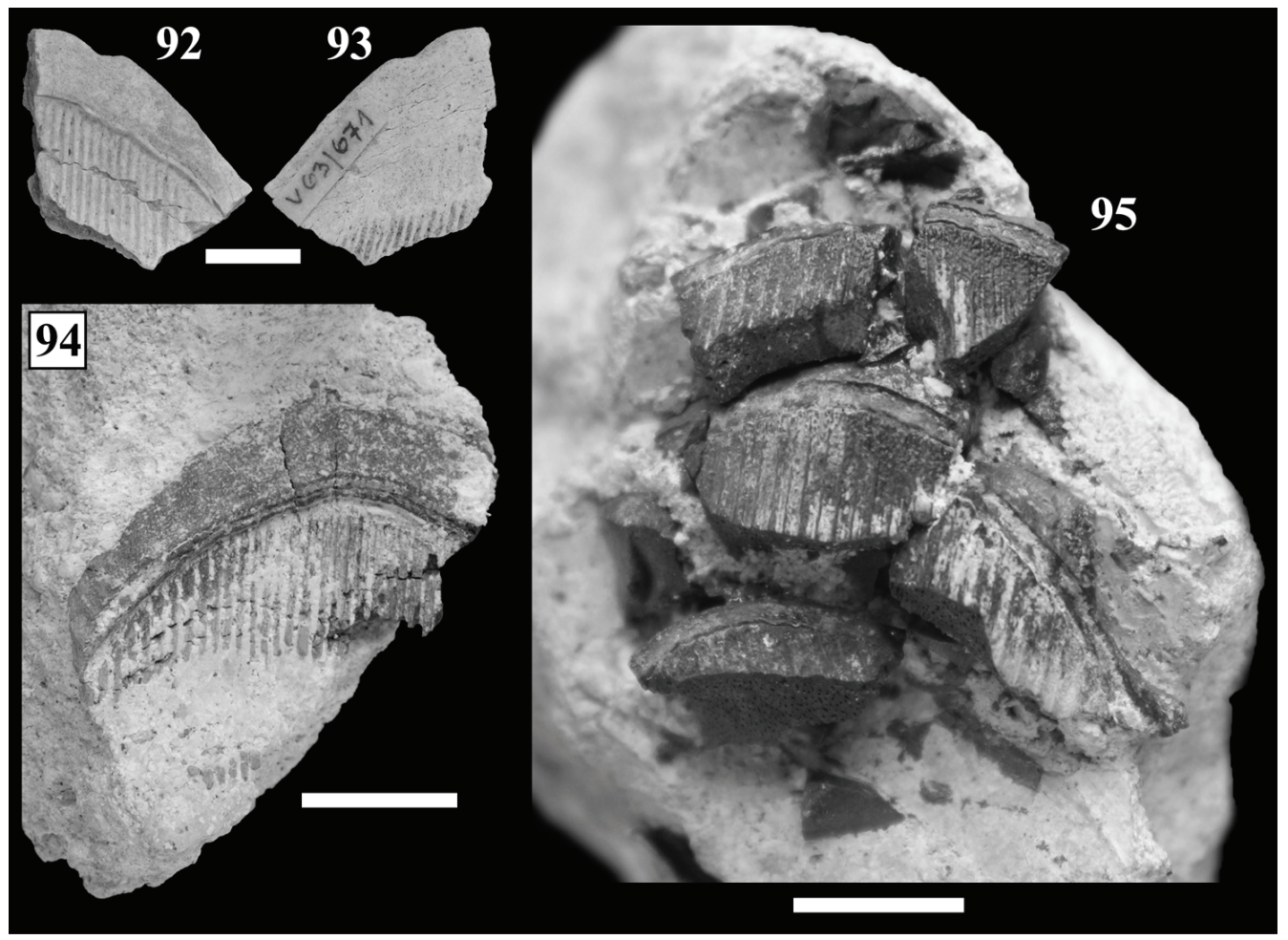

Figs 92-95. Aetobatus arcuatus (Agassiz, 1843). - Figs 92-93. Lower tooth, V.63.671. - Fig. 92. Apical view. - Fig. 93. Basal view. - Fig. 94. Lower tooth, V.61.913, apical view. - Fig. 95. Three associable teeth of a lower tooth plate, V.61.936, ?basal view. Scale bars: $10 \mathrm{~mm}$ 
from the root by a lingual bulge. The root is lingually shifted, it is built up by long, distally inclined laminae (Figs 92-94). Specimen V.61.936 is a partial upper dentition, consisting of at least 3 teeth (Fig. 95).

Remarks - Dentition of genus Aetobatus consists of a single row of teeth, in a conveyor-like, horizontal arrangement both in the upper and lower jaw (BOR et al. 2012; Hovestadt \& Hovestadt-Euler 2013). Fossil species $A$. arcuatus is widely known from the Badenian Central Paratethys (SzABó \& Kocsis 2016, table 2).

\section{Osteichthyans}

A large piece of laminated marly Leitha Limestone is inventoried as Clypea haidingeri Heckel, 1850 (V.61.1277, Figs 96-97). The marly plate includes imprints and bony portions of the skeletons of three individuals, preserved in lateral aspect. Two of them have the skull preserved, however, both require further preparation.

The holotype specimen of Caranx boeckii (originally described as Caranx böckhi by GorJANOvić-KRAMBERger 1902) is described from St. Margarethen. The fish is preserved in two pieces of laminated marl as part and counterpart (V.69.244 and V.69.277, Figs 98-99). It is noteworthy that PÁLFY et al. (2008) assigned only specimen V.69.244 to the type material. The fish is of good condition, however, a careful preparation of the specimen could reveal further anatomical details, helping to verify the validity of $C$. boeckii, which is beyond the scope of the present study. V.62.406 (not figured) is also referred to C. boeckii, however, this assignment seems to be questionable, considering the relatively poor preservation of the specimen.

A pharyngeal tooth plate is referable to an indeterminate Labridae (V.62.407, Figs 100-101). The plate is sitting in a piece of Leitha Limestone, and is of triangular outline in occlusal view. It bears low, circular to oval crushing teeth, among which the largest ones are positioned in the mediolateral midline. SCHULTZ (2013, pl. 69, figs 3a, b) figured a pharyngeal plate similar to V.62.407, which was found at St. Margarethen, and was referred to as Labridae indet.

A fragmentary left premaxillary bone is assigned to Sparus umbonatus (Münster, 1846) (V.62.407, Fig. 102). The tooth bearing portion is of triangular shape, it has more than 20 tooth bases but only one in situ tooth preserved. A tooth position corresponding to an enlarged, posterior molariform tooth, characteristic for S. umbonatus is clearly visible. Schultz et al. (2010, pl. 3, fig. 11) figured a comparable premaxillary of $S$. umbonatus from the Middle Miocene of Kienberg (Czech Republic). The species has been previously reported from St. Margarethen by SCHMid et al. (2001, pl. 8, fig. 1) and Schultz (2013, pl. 68, fig. 1). 
A fragmentary premaxillary (V.62.393, Figs 103, 104), different from V.62.407 in being more slender and showing relatively larger tooth bases is assigned to an indeterminate sparid. Fourteen tooth positions are preserved, two



Figs 96-97. Clypea haidingeri Heckel, 1850. - Fig. 96. V.61.1277. - Fig. 97. Close-up of one of the exposed fish individuals in the same specimen. - Figs 98-99. Caranx boeckii GorjanovićKramberger, 1902 (holotype). - Fig. 98. V.69.244. - Fig. 99. V.69.277, counter-part. Scale bars: Fig. 96: 5 cm; Fig. 97: 10 mm; Figs 98-99: $10 \mathrm{~cm}$ 


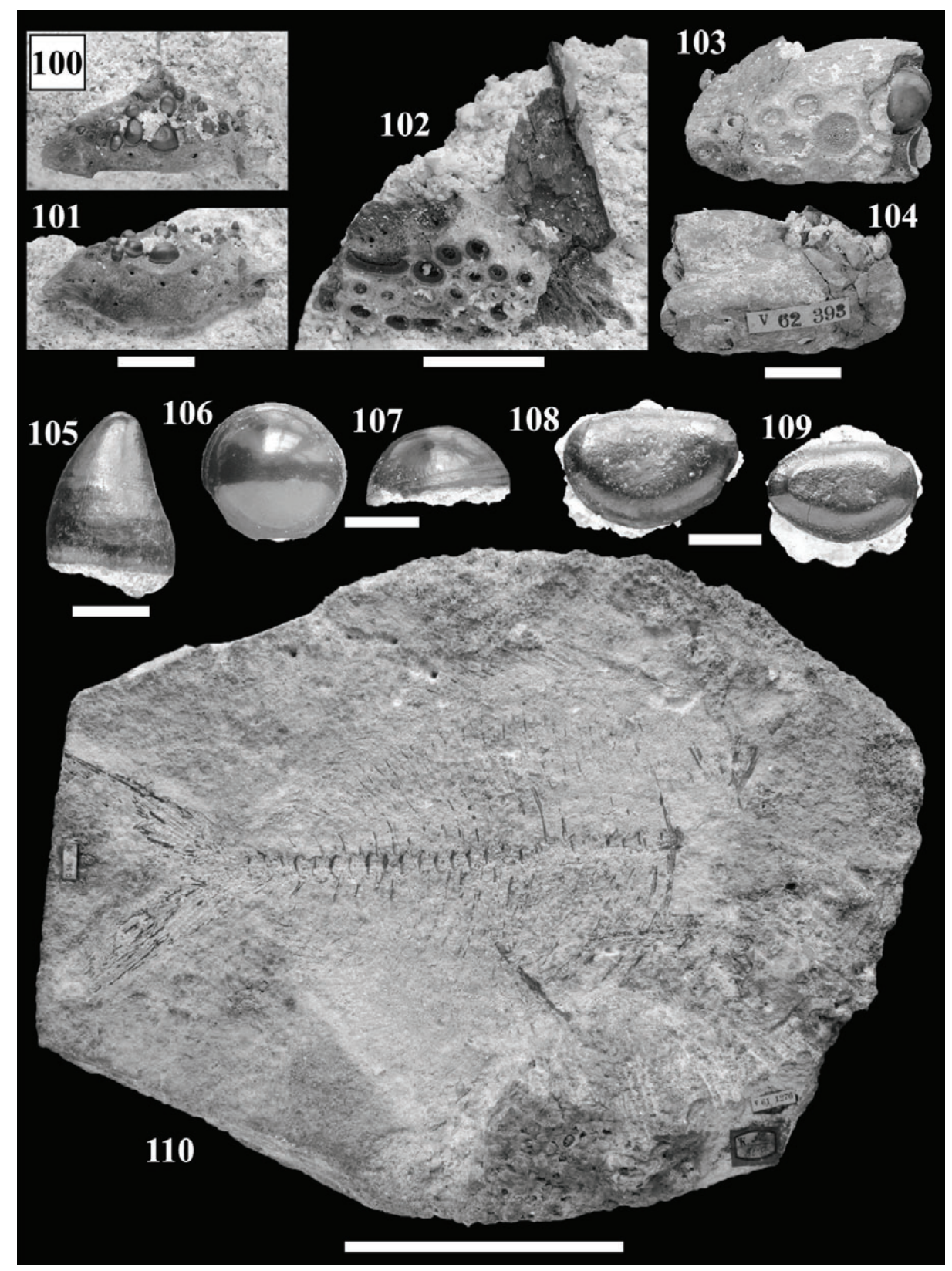

Figs 100-101. Labridae indet. pharyngeal tooth plate, V.62.407. - Fig. 100. Occlusal view. Fig. 101. Posterior view. - Fig. 102. Sparus umbonatus (Münster, 1846), premaxillary, V.62.407, medial view. - Figs 103-109. Sparidae indet. remains. - Figs 103-104. Fragmentary premaxillary, V.62.393. - Fig. 103. Medial view. - Fig. 104. Lateral view. - Fig. 105. Caniniform tooth, V.69.1088, profile view. - Figs 106-107. Molariform tooth, V.62.413. - Fig. 106. Occlusal view. Fig. 107. Profile view. - Figs 108, 109. Molariform teeth, both V.63.481, occlusal view. - Fig. 110. Osteichthyes indet. partial skeleton, V.61.1276, lateral view. Scale bars: Figs 100-101, 106-109: 5 mm; Figs 102-104: 10 mm; Fig.105: 3 mm; Fig. 110: $10 \mathrm{~cm}$ 
with a tooth inside. Although this bone is very similar to premaxillary of Pagrus cinctus (Agassiz, 1839), a species widely abundant in the Miocene of Europe, it is too incomplete for a more certain identification. Isolated caniniform and molariform teeth of sparids, some are embedded in a piece of Leitha Limestone, are also housed in the HNHM collection. Caniniform teeth are of anterior position, with conical morphology (Fig. 105), while molariforms are placed more posteriorly, and are oval to circular in occlusal view (Figs 106-109). Due to their similar morphology, isolated teeth of sparid fishes are hard to distinguish at lower taxonomic level.

A large-sized, partial skeleton is referred to an indeterminate osteichthyan (V.61.1276, Fig. 110). The fish is mostly preserved as imprint only; therefore, a closer identification is not attempted.

\section{HISTORICAL CONTRIBUTIONS}

The Hungarian Natural History Museum, as part of the Hungarian National Museum at that time, was hit by artillery fire in the October of 1956 . The value of the departmental damages is barely calculable, since the flames ate up a significant per cent of the inventory books and index cards, not to mention that some losses are scientifically invaluable, since the destroyed fossil material contained many type specimens (Boros 1957, KeCSKemÉTi 2016). The fact, that at least a part of the St. Margarethen material had already been in the HNHM collection long before the revolution (see below), and they survived both the fire and the moving of the museum collection after the tragedy, makes this material an extremely important part of the HNHM palaeontological collection from the scientific historical point of view. Intensive investigations of this material through more than one and a half centuries add new data to our knowledge on the Middle Miocene (Badenian) St. Margarethen fish fauna.

\section{DISCUSSION}

Schmid et al. (2001) reported the following chondrichthyans from the Kummer quarry at St. Margarethen: Carcharias acutissimus, Keasius parvus, Carcharhinus priscus, Pristis sp., Dasyatoidea or Myliobatoidea, and Aetobatus arcuatus from the Unit I (laminated marl facies); Araloselachus cuspidatus, Otodus (Megaselachus) megalodon, Keasius parvus, Galeocerdo aduncus, Dasyatoidea or Myliobatoidea, and Aetobatus arcuatus from Unit II (rudstones). Later SCHULTZ (2013) added further faunal data, as he listed Myliobatiformes indet., Myliobatidae or Rhinopteridae indet. as well. However, the St. Margarethen chondrichthyan material of the HNHM collection represents taxa typical for the 


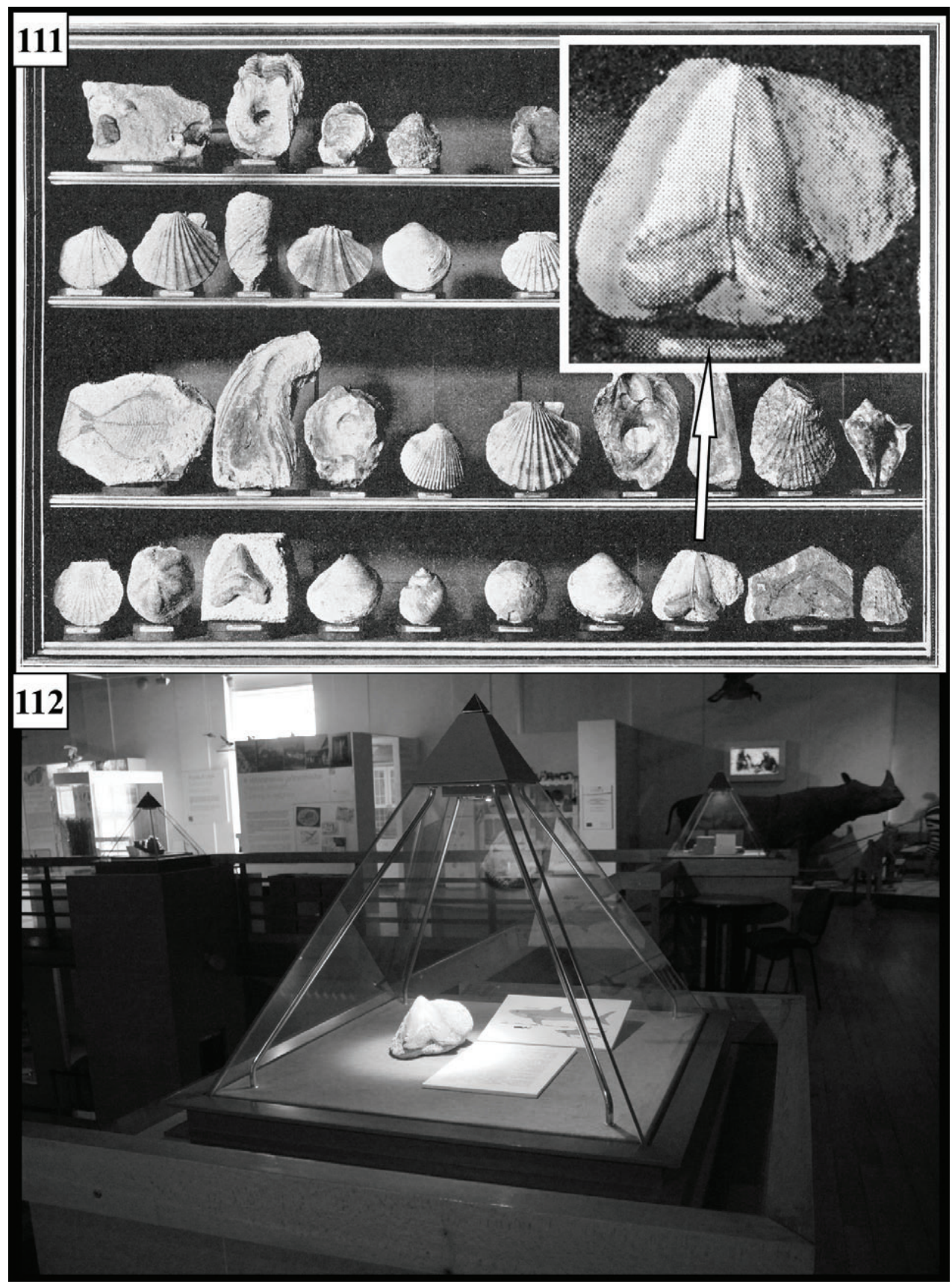

Fig. 111. Old vitrine showing collection specimens of the Hungarian National Museum (modified after NAGY et al. 1902), with the picture of Otodus (Megaselachus) megalodon tooth, V.60.1741, enlarged; note that specimens V.61.1277 (C. haidingeri) and V.61.276 (Osteichthyes indet.) are also exhibited in the vitrine. Fig. 112. Otodus (Megaselachus) megalodon tooth specimen, V.60.1741, as part of the permanent palaeontological exhibition of the Hungarian Natural History Museum (picture by the author, 2019) 
Badenian of the Central Paratethys, yet, some of them have never been reported from the locality before, and some reported forms of SCHMID et al. (2001), e.g. $A$.cuspidatus might be worth a revision (see $A$. vorax in Systematic Palaeontology of the present study).

Although a large number of fish fossils from the vicinity of St. Margarethen are housed in the collection of the Naturhistorisches Museum in Vienna (Wien, Austria), up to now, such complete, partially articulated remains of chondrichthyans as specimen VER 2020.69.1. (and its isolated portions) have been unknown from the St. Margarethen quarries. It is worth mentioning that associated elements of cartilaginous fishes, including associable gill rakers of Keasius parvus and a fragmentary portion of the skin of Pristis sp. with in situ denticles have been found (SCHMID et al. 2001; SCHULtz 2013; Carnevale pers. comm.).

The importance of the specimen is further increased by the presence of the four morphotypes of associable placoid scales and by the portions of the possible cartilage, possibly that of a jaw arch. The separated occurrence and the large differences of the morphotypes further demonstrate that placoid scales of sharks are morphologically very diverse according to the location on skin, including the oral cavity (after Reif 1985; At Kinson \& Collin 2012; Chernova \& Vorob'eva 2012; Ciena et al. 2015;). As the sculpture of dermal denticle crowns is taxon specific in some extant forms (CHERNOVA \& Vorob'EVA 2012), the diagnostic value of specimen VER 2020.69.1. and its belonging parts is of great importance. However, the question, whether the placoid scale morphotypes of specimen VER 2020.69.1. represent both dermal and oral denticles, remains unsolved. The discussion of this question is beyond the scope of the present paper, but could be a basis for a future study, as oral and dermal denticles have different function.

Solt (1988) described articulated vertebrae and associable jaw and tooth remains of $C$. divergens from the early Oligocene (Kiscellian) Tard Clay Formation of the Csillaghegy brickyard (Budapest, Hungary). However, of this material, Solt (1988) reported "skin remains" preserved, which seem to be portions of mosaic cartilage tissue (pers. obs. 2018). This fossil, now housed in the vertebrate fossil collection of the Mining and Geological Survey of Hungary (Budapest), represents the first articulated shark fossil described from the Carpathian Basin. The fact that specimen VER 2020.69.1. and its isolated portions represent the second (belonging to the same shark family), further highlights the importance of this specimen. It is noteworthy that MARRAMÀ et al. (2019) described the rajiform species Ostarriraja parva based on a nearly complete, articulated skeleton from the Early Miocene of Rainbach im Innkreis (Upper Austria; Central Paratethys). 
An Otodus (Megaselachus) megalodon tooth specimen V.60.1741 is the largest tooth in the HNHM vertebrate palaeontological collection, belonging to this species. It was first figured in 1902 (together with V.61.1277 [C. haidingeri], and V.61.276 [indeterminate osteichthyan]; see Fig. 111), in a short guidebook (NAGY et al. 1902) presenting the mineralogical and palaeontological collection (in 1902 the Hungarian Natural History Museum was the part of Hungarian National Museum), and proving that this tooth has been housed in the collection for at least 118 years. Because of its impressive size and exceptionally good condition, this tooth is currently the part of the permanent palaeontological exhibition of the HNHM (Fig. 112).

However, the St. Margarethen bony fish fossils of the HNHM vertebrate palaeontological collection are only shortly mentioned here. As these include the holotype of Caranx boeckii, a species requiring a revision, this part of the collection is of great importance. A detailed elaboration of these fish fossils may be a part of a future study.

The importance of the revision of further sections of the HNHM vertebrate palaeontological collections is emphasized. A large number of specimens from the Miocene of Fertőrákos (Hungary), Felsőesztergály (Horné Strháre, Slovakia), and Dévényújfalu (Devínska Nová Ves, Slovakia) are also housed in the HNHM collection. As the vertebrate fauna of these localities is not, poorly or incompletely documented, or the related taxonomic literature is worth a revision by the account of its age (Koch 1903; Kordos \& Solt 1984; HoleC 2001), these HNHM materials are credited with a great significance in case of related studies in the future.

Acknowledgements - The author wishes to especially thank Jürgen Pollerspöck for his constructive comments regarding an earlier version of the manuscript and also for his active help regarding hardly available literatures. Giorgio Carnevale is acknowledged for his help regarding specimens of Naturhistorisches Museum Wien. The author is grateful to Adam Anderson, Peter Picard and Rene van der Vliet for the useful conversations over problematic specimens. Krisztina Buczkó is thanked for her help in scanning electron microscopy. The webpages of elasmo.com and shark-references.com are highly acknowledged here. All colleagues of the HNHM Department of Palaeontology and Geology are acknowledged for their assistance and patience.

\section{REFERENCES}

Agassiz L. 1838: Recherches sur les poissons fossiles, 11th livraison (November 1838). - Petitpierre et Prince (text) and H. Nicolet (plates), Neuchâtel, vol. 3: [73]-140, pl. 1a, 8a, 8b, 15, 17, 19, 20, 24, 25b, 30, 31, 32, 33, 34, 35, 39, 40. 
Atkinson C. J. L. \& Collin S. P. 2012: Structure and topographic distribution of oral denticles in elasmobranch fishes. - Biological Bulletin 222(1): 26-34.

https://doi.org/10.1086/BBLv222 n1p26

BÁLDI T. 1983: Magyarországi oligocén és alsómiocén formációk. [Hungarian Oligocene and Lower Miocene formations.] - Akadémiai Kiadó, Budapest, 293 pp. (in Hungarian)

Bor T. J., Reinecke T. \& Verschueren S. 2012: Miocene Chondrichthyes from WinterswijkMiste, the Netherlands. - Palaeontos 21: 1-136.

Boros I. 1957: The tragedy of the Hungarian Natural History Museum. - Annales historico-naturales Musei nationalis hungarici 49: 491-505.

Cappetta H. 2012: Handbook of Paleoichthyology, Vol. 3E: Chondrichthyes. Mesozoic and Cenozoic Elasmobranchii: Teeth. - Verlag Dr. Friedrich Pfeil, 512 pp.

Carnevale G. \& Collette B. B. 2014: †Zappaichthys harzhauseri, gen. et sp. nov., a new Miocene toadfish (Teleostei, Batrachoidiformes) from the Paratethys (St. Margarethen in Burgenland, Austria), with comments on the fossil record of batrachoidiform fishes. Journal of Vertebrate Paleontology 34(5): 1005-1017.

Carnevale G. \& Harzhauser M. 2013: Middle Miocene rockling (Teleostei, Gadidae) from the Paratethys (St. Margarethen in Burgenland, Austria). - Bulletin of Geosciences 88(3): 609-620.

Carnevale G. \& Tyler J. C. 2014: A new pufferfish (Teleostei, Tetraodontidae) from the Middle Miocene of St. Margarethen, Austria. - Paläontologische Zeitschrift 89(3): 435-447. https://doi.org/10.1007/s12542-014-0243-3

Chanet B. \& Schultz O. 1994: Pleuronectiform fishes from the upper Badenian (Middle Miocene) of St. Margarethen (Austria). - Annalen des Naturbistorischen Museums in Wien 96A: 95-115.

Chernova O. F. \& Vorob'eva E. I. 2012: Polymorphism of the Surface Sculpture of Placoid Scales of Sharks (Selachomorpha, Elasmobranchii). - Doklady Biological Sciences 446(1): 316-319. https://doi.org/10.1134/S0012496612050067

Ciena A. P., Rangel B. De S., Bruno C. E. M., Miglino M. A., Amorim A. F. De, Rici R. E. G. \& WatanabE I. 2015: Morphological aspects of oral denticles in the sharpnose shark Rhizoprionodon lalandii (Müller and Henle, 1839) (Elasmobranchii, Carcharhinidae). - Anatomia, Histologia, Embryologia 45(2): 109-114. https://doi.org/10.1111/ahe.12178

De SCHutTER P. J. 2011: Carcharias vorax (Le Hon, 1871) (Chondrichthyes: Lamniformes), from the Miocene of Belgium: redescription and designation of a neotype and paraneotype. Geologica Belgica 14(3-4): 175-192.

Dullo W. C. 1983: Fossildiagenese im miozänen Leitha-Kalk der Paratethys von Österreich: Ein Beispiel für Faunenverschiebung durch Diageneseunterschiede. - Facies 8: 1-112.

Ebert D. A., Fowler S. \& Compagno L. J. V. 2013: Sharks of the World - A fully illustrated guide. - Wild Nature Press, 528 pp.

Ehret D. J., Macfadden B. J., Jones D. S., Devries T. J., Foster D. A. \& Salas-Gismondi R. 2012: Origin of the white shark Carcharodon (Lamniformes: Lamnidae) based on recalibration of the Upper Neogene Pisco Formation of Peru. - Paleontology 6: 1139-1153.

GorJanović-Kramberger K. 1902: Paleoichthyologiai adalékok. [Palaeoichthyological data.] Magyar Királyi Földtani Intézet Évkönyve 1899-1911 14(5): 3-20.

Gradstein F. M., Ogg J. G., Schmitz M. \& OgG G. 2012: The Geological Time Scale 2012, vols. 1 \& 2. - Elsevier Science Ltd., Oxford, 1176 pp.

Harzhauser M. \& Piller W. E. 2004: The Early Sarmatian - hidden seesaw changes. - Courier Forschungsinstitut Senckenberg 246: 89-111. 
Harzhauser M. \& Piller W. E. 2010: Molluscs as a major part of subtropical shallow-water carbonate production - an example from a Middle Miocene oolite shoal (Upper Serravallian, Austria). - International Association of Sedimentologists, Special Publications 42: 185-200. https://doi.org/10.1002/9781118398364.ch11

Hohenegger J., Ćorić S. \& WAgreich M. 2014: Timing of the Middle Miocene Badenian Stage of the Central Paratethys. - Geologica Carpathica 65(1): 55-66.

Holec P. 2001: Chondrichthyes and Osteichthyes (Vertebrata) from Miocene of Vienna Basin near Bratislava (Slovakia). - Mineralia Slovaca 33: 111-134. (in Slovak with English abstract)

Holec P., Hornáčex M. \& SÝkora M. 1995: Lower Miocene Shark (Chondrichthyes, Elasmobranchii) and Whale Faunas (Mammalia, Cetacea) near Mučín, Southern Slovakia. - Geologické práce 100: 37-52.

Hovestadt D. C. \& Hovestadt-Euler M. 2010: A partial skeleton of Carcharias gustrowensis (Winkler, 1875) (Chondrichthyes, Odontaspididae) including embryos, a chimaeriod dorsal fin spine and a myliobatoid tail spine from the Oligocene of Germany. - Cainozoic Research 7(1-2): 83-97.

Hovestadt D. C. \& Hovestadt-Euler M. 2013: Generic Assessment and Reallocation of Cenozoic Myliobatinae based on new information of tooth, tooth plate and caudal spine morphology of extant taxa. - Palaeontos 24: 1-66.

KeCsKemÉTi T. 2016: Tüzvész a múzeumban (1956). Egy tanú visszaemlékezései. (Conflagration of the museum (1956). Recollection of a witness.) - Annales Musei historico-naturalis hungarici 108: 127-149.

KefERSTEIN C. 1828: Beobachtungen und Ansichten über die geognostischen Verhältnisse der nördlichen Kalk-Alpenkette in Österreich-Bayern. Teutschland geognostisch-geologisch dargestellt. Weimar, $425 \mathrm{pp}$.

KENT B. W. 2018: The cartilaginous fishes (Chimaeras, Sharks, and Rays) of Calvert Cliffs, Maryland, USA. - In: Godfrey S. J. (ed.): The geology and vertebrate paleontology of Calvert Cliffs, Maryland. - Smithsonian Institution Scholarly Press, Washington D. C., pp. 161-212.

Kocsis L. 2007: Central Paratethyan shark fauna (Ipolytarnóc, Hungary). - Geologica Carpathica 58(1): 27-40.

Kосн A. 1903: Tarnócz Nógrád megyében mint kövült czápafogaknak új gazdag lelőhelye. [Tarnócz, in Nógrád county, as new and rich locality for fossil shark teeth.] - Földtani Közlöny 33: 22-44. (in Hungarian)

Kordos L. \& SOLT P. 1984: A magyarországi miocén tengeri gerinces faunaszintek vázlata. [Sketch of the marine vertebrate fauna levels of the Miocene of Hungary.] - A Magyar Állami Földtani Intézet Évi Jelentése 1982-ról, pp. 347-351. (in Hungarian)

Kováč M., Andreyeva-Grigorovich A., BajRa ktarević Z., BrzobohatÝ R., Filipescu S., Fodor L., Harzhauser M., Oszczypko N., Pavelic D., Rögl F., Saftić B., Sliva L. \& Studencka B. 2007: Badenian evolution of the Central Parathethys sea: paleogeography, climate and eustatic sea level changes. - Geologica Carpathica 58: 579-606.

KozUCH L. \& Fitzgerald C. 1989: A guide to identifying shark centra from southeastern archaeological sites. - Southeastern Archaeology 8(2): 146-157.

Le Hon H. 1871: Préliminaries d'un mémoire sur les poissons tertiaires de Belgique. - Bruxelles, Brochure de 15 pages.

Maisch H. M., Becker M. A. \& Chamberlain J. A. 2018: Lamniform and carcharhiniform sharks from the Pungo River and Yorktown Formations (Miocene-Pliocene) of the submerged continental shelf, Onslow Bay, North Carolina, USA. - Copeia 106(2): 353-374. 
Marramà G., Schultz O. \& Kriwet J. 2019: A new Miocene skate from the Central Paratethys (Upper Austria): the first unambiguous skeletal record for the Rajiformes (Chondrichthyes: Batomorphii). - Journal of Systematic Palaeontology 17(11): 937-960. https://doi.org/10.10 80/14772019.2018.1486336

Münster G. G. 1846: Ueber die in der Tertiär-Formation des Wiener Beckens vorkommenden Fisch-Ueberreste, mit Beschreibung eininger neuen merkwürdigen Arten. - Beiträge zur Petrefactenkunde 7: 1-31.

NAGy G., RÉthy L., SChönherr Gy., Sebestyén Gy., VArjú E., ÁldÁsy A. \& MocsÁry S. 1902: A Magyar Nemzeti Múzeum múltja és jelene. Alapitása századik évfordulója alkalmából irták a Magyar Nemzeti Múzeum tisztviselöi. [Past and present of the Hungarian National Museum. Written by its officials on the occasion of the 100th anniversary of the museum's establishment.] Budapest, Hornyánszky Viktor nyomdája, Nagy 4r., XL, 382+2 pp. (in Hungarian)

Nelson J. S., Grande T. C. \& Wilson M. V.H. 2016: Fishes of the World. 5th Edition. - Hoboken, New Jersey, John Wiley \& Sons, 707 pp.

PAPP A., Cicha I., Seneš J. \& STEININGER F. 1978: Chronostratigraphie und Neostratotypen. Miozän der Zentralen Paratethys: M4-Badenien (Moravien, Wielicien, Kosovien). - Slowakische Akademie der Wissenschaften, Bratislava, $594 \mathrm{pp}$.

PILler W. E. 1994: Nullipora ramosissima Reuss, 1847 - a re-discovery. - Beiträge zur Paläontologie 19: $181-189$.

Pálfy J., Dulai A., Gasparik M., Ozsvárt P., Pazonyi P. \& Szives O. 2008: Catalogue of invertebrate and vertebrate paleontological type specimens of the Hungarian Natural History Museum. - Hungarian Natural History Museum, Budapest, 209 pp.

Purdy W. R., Schneider P. V., Applegate P. S., Mclellan H. J., Meyer L. R. \& Slaughter H. B. 2001: The Neogene sharks, rays, and bony fishes from Lee Creek Mine, Aurora, North Carolina. - In: RAY C. E. \& BohasKa D. J. (eds): Geology and paleontology of the Lee Creek Mine, North Carolina, III. - Smithsonian Contributions to Paleobiology 90: 71-202.

RADWAŃski A. 1965: A contribution to the knowledge of Miocene Elasmobranchii from Pinczów (Poland). - Acta Palaeontologica Polonica 10(2): 267-269.

REIF W.-E. 1985: Squamation and Ecology of Sharks. - Courier Forschungsinstitut Senckenberg 78: $1-255$.

Reinecke T., Louwye S., Havekost U. \& Moths H. 2011: The elasmobranch fauna of the Late Burdigalian, Miocene, at Werder-Uesen, Lower Saxony, Germany, and its relationships with Early Miocene faunas in the North Atlantic, Central Paratethys and Mediterranean. Palaeontos 20: 1-170.

Reinecke T., Balsberger M., Beaury B. \& Pollerspöck J. 2014: The elasmobranch fauna of the Thalberg Beds, Early Egerian (Chattian, Oligocene), in the Subalpine Molasse Basin near Siegsdorf, Bavaria, Germany. - Palaeontos 26: 1-127.

Riegl B. \& Piller W. E. 2000: Biostromal coral facies - a Miocene example from the Leitha Limestone (Austria) and its actualistic interpretation. - Palaios 15: 399-413.

RöGL F. 1998: Palaeogeographic considerations for the Mediterranean and Paratethys seaways (Oligocene to Miocene). - Annalen des Naturhistorischen Museums in Wien 99A: 279-310.

Rögl F. \& Steininger F. F. 1983: Vom Zerfall der Tethys zu Mediterran und Paratethys. Die neogene Paläogeographie und Palinspastik des zirkum-mediterranen Raumes. - Annalen des Naturbistorischen Museums in Wien 84A: 135-163. 
Rögl F., Ćorić S., Harzhauser M., Jimenez-Moreno G., Kroh A., Schultz O., Wessely G. $\&$ ZoRn I. 2008: The Middle Miocene Badenian stratotype at Baden-Sooss (Lower Austria). - Geologica Carpathica 59(5): 367-374.

Sauer R., Seifert P. \& Wessely G. 1992: Guidebook to excursions in the Vienna Basin and the adjacent Alpine-Carpathian thrustbelt in Austria. - Mitteilungen der Geologischen Gesellschaft 85: $1-264$.

Schmid H. P., Harzhauser M. \& Kroh A. 2001: Hypoxic events on a Middle Miocene Carbonate Platform of the Central Paratethys (Austria, Badenian, $14 \mathrm{Ma}$ ). - Annalen des Naturhistorisches Museums in Wien 102A: 1-50.

Schultz O. 1971: Die Selachier-Fauna (Pisces, Elasmobranchii) des Wiener Beckens und seiner Randgebiete im Badenien (Miozän). - Annalen des Naturhistorischen Museums in Wien 75: 311-341.

Schultz O. 2013: Pisces. - In: Piller W. (ed.) Catalogus Fossilium Austriae, Bd. 3; Verlag der Österreichischen Akademie der Wissenschaften, Wien, 576 pp.

Schultz O., Brzobohatý R. \& Kroupa O. 2010: Fish teeth from the Middle Miocene of Kienberg at Mikulov, Czech Republic, Vienna Basin. - Annalen des Naturbistorisches Museums in Wien 112A: 489-506.

Solt P. 1988: Odontaspis (Synodontaspis) divergens n. sp. from the Oligocene of Csillaghegy. Annual Report of the Hungarian Geological Institute of 1986, pp. 519-533.

Stone N. R. \& Shimada K. 2019: Skeletal anatomy of the Bigeye Sand Tiger Shark, Odontaspis noronhai (Lamniformes: Odontaspididae), and its implications for lamniform phylogeny, taxonomy, and conservation biology. - Copeia 107(4): 632-652.

STUdENCKI W. 1988: Facies and sedimentary environment of the Pinczow Limestones (Middle Miocene; Holy Cross Mountains, Central Poland). - Facies 18: 1-26.

Szabó M. \& Kocsis L. 2016: A new Middle Miocene selachian assemblage (Chondrichthyes, Elasmobranchii) from the Central Paratethys: implications for temporal turnover and biogeography. - Geologica Carpathica 67(6): 573-594. https://doi.org/10.1515/geoca-2016-0036

Szabó M. \& Kocsis L. 2020: Supplementary data on the Middle Miocene (Badenian) fish assemblage of Nyirád (Hungary): revision and new results on faunal composition and paleoenvironment. - Palaeontographica, Abt. A: Palaeozoology-Stratigraphy 315(5-6): 121-192. https://doi.org/10.1127/pala/2020/0094

Szabó M., Botfalvai G., Kocsis L., Carnevale G., Sztanó O., Evanics Z. \& Rabi M. 2017: Upper Oligocene marine fishes from nearshore deposits of the Central Paratethys (Máriahalom, Hungary). - Palaeobiodiversity and Palaeoenvironments, https://doi.org/10.1007/s12549-017-0285-0

Tollmann A. 1985: Geologie von Österreich. Band II. - Außerzentralalpiner Anteil, Deuticke, Wien, $710 \mathrm{pp}$.

Trif N. \& Codrea V. 2017: Some Badenian fish teeth from western Transylvania (Romania). Muzeul Olteniei Craiova, Oltenia, Studii şi comunicări, Ştiințele Naturii 33(1): 7-17.

Ward D. J. \& Bonavia C. G. 2001: Additions to, and a review of, the Miocene shark and ray fauna of Malta. - The Central Mediterranean Naturalist 3(3): 131-146.

Wessely G. 1983: Zur Geologie und Hydrodynamik im südlichen Wiener Becken und seiner Randzone. - Mitteilungen der österreichischen geologischen Gesellschaft 76: 27-68. 


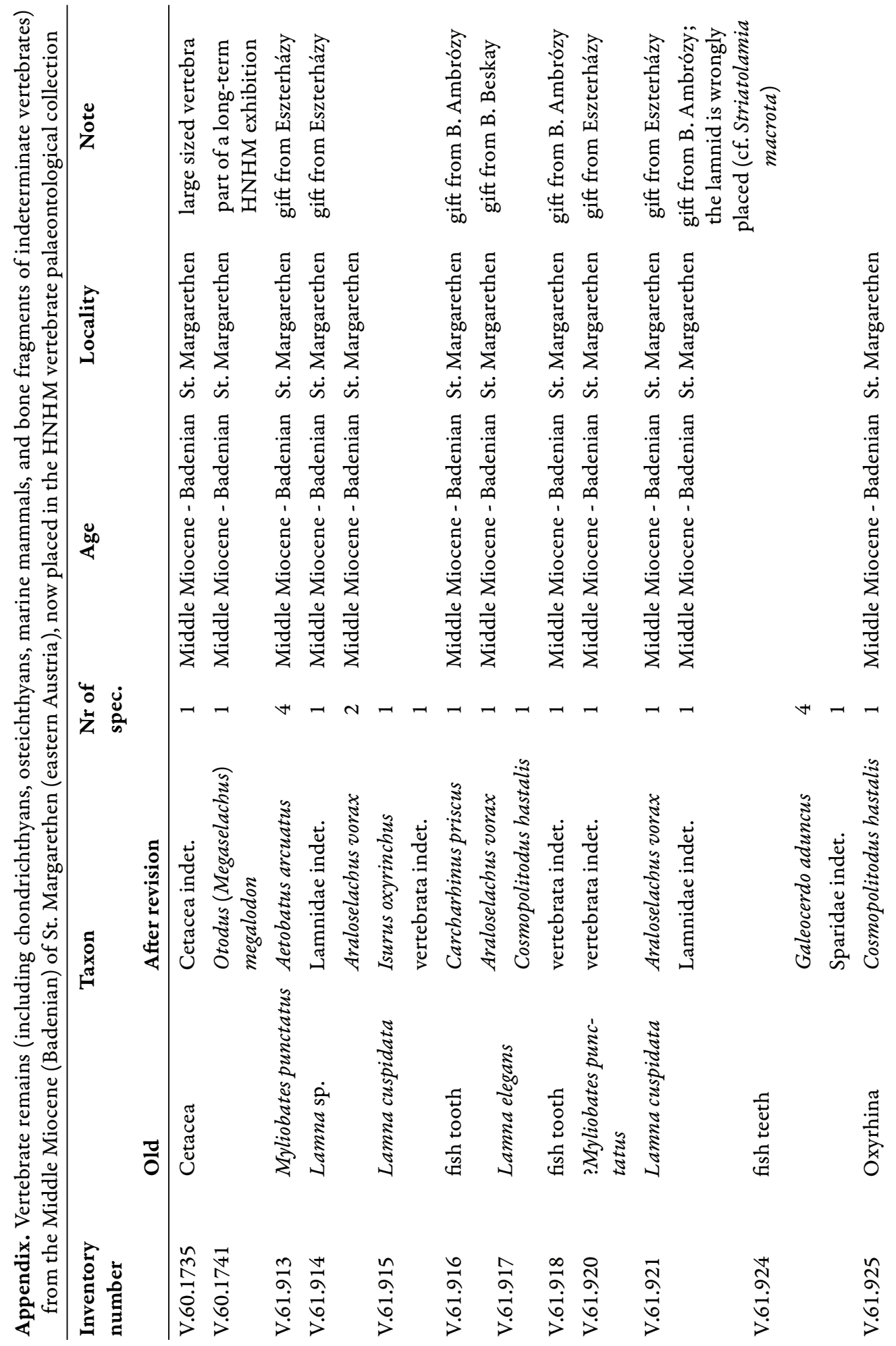



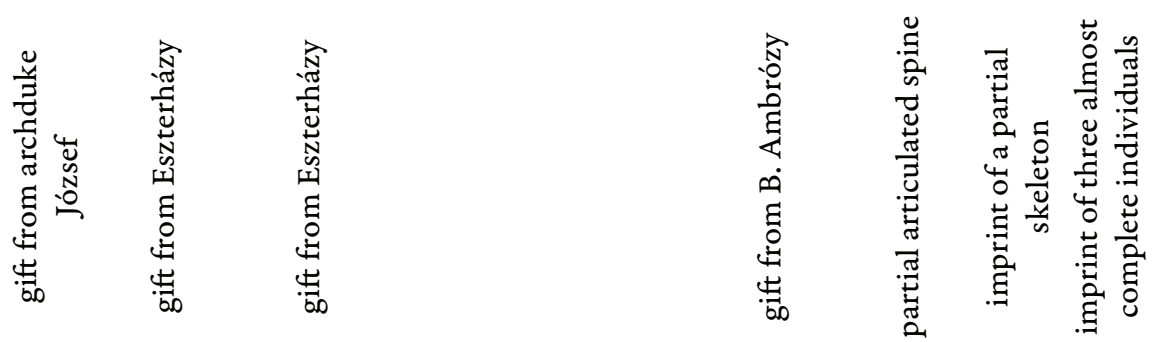

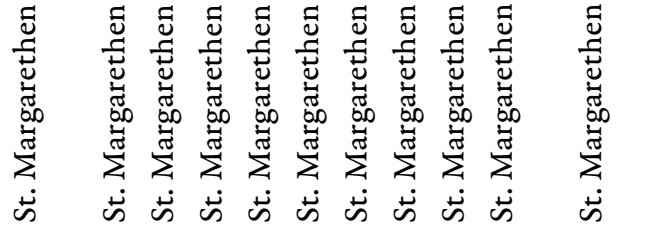

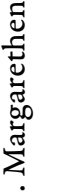

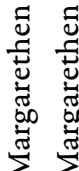

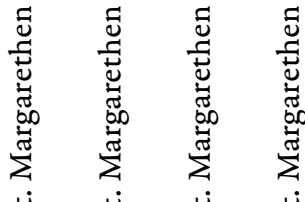

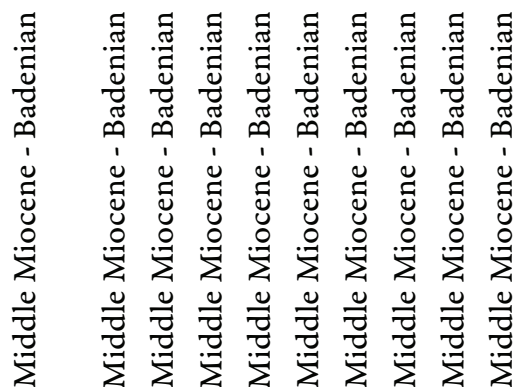

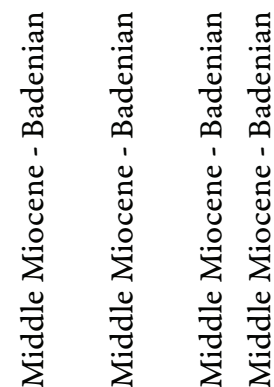

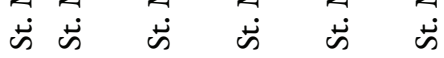

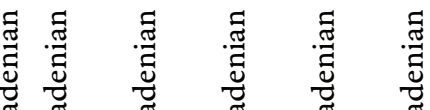

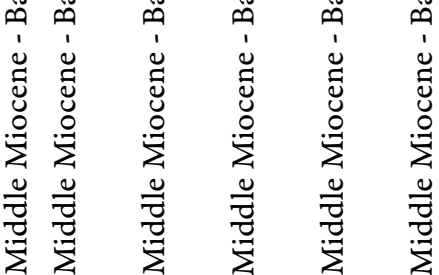

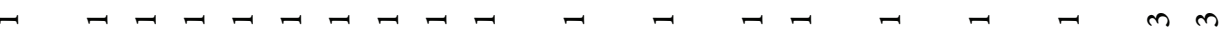

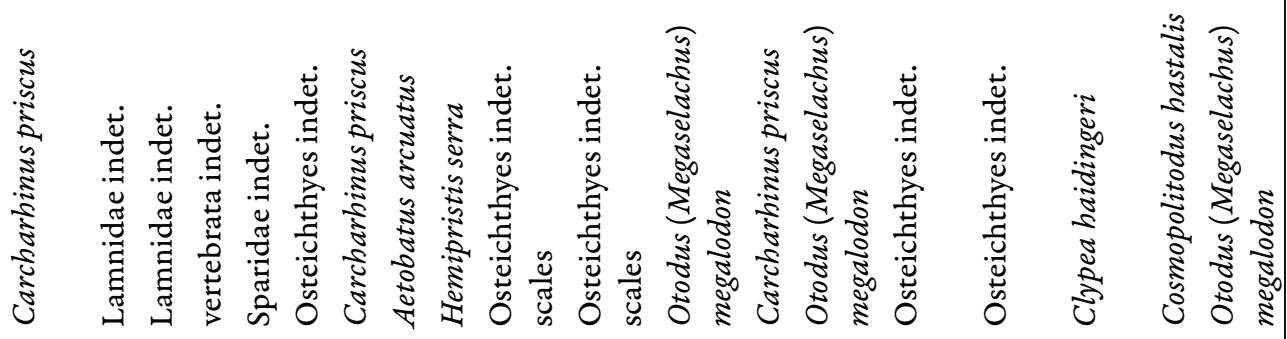

㻤

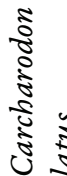

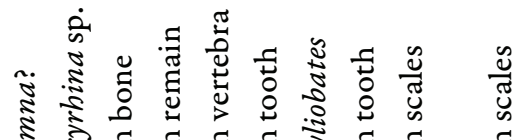

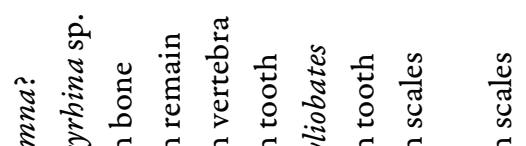

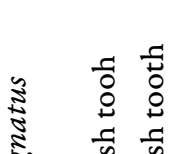

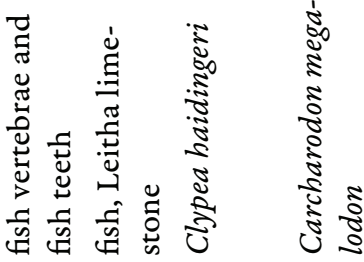

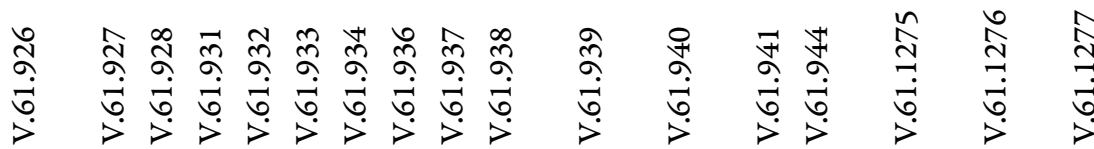

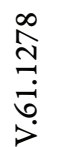




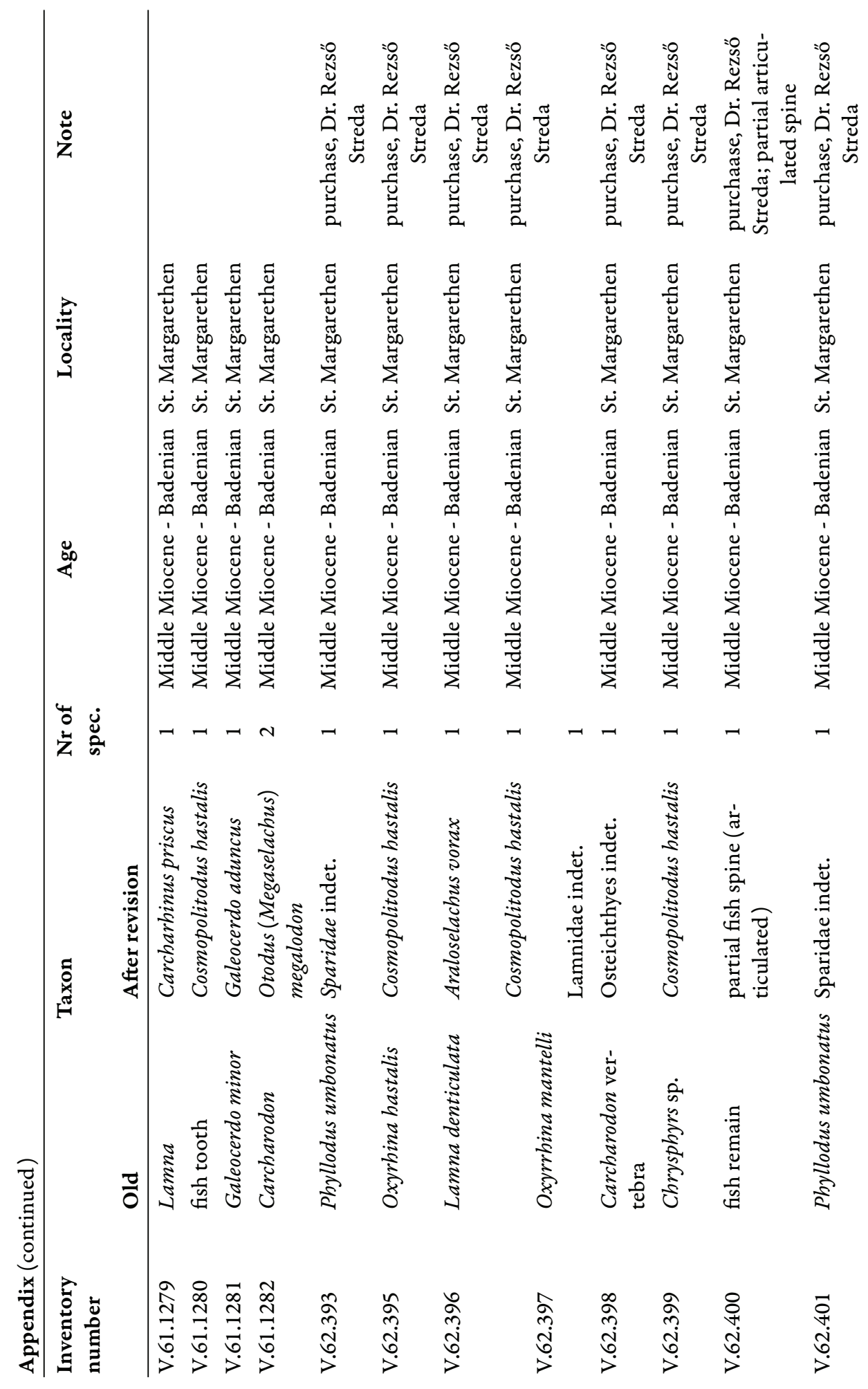




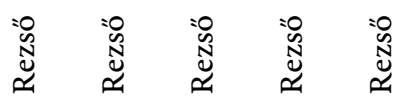

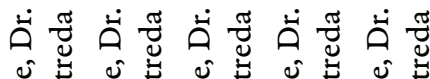

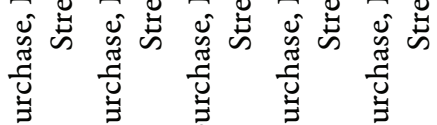

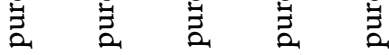

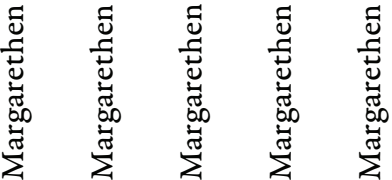

$\dot{\omega} \dot{\infty} \dot{\infty} \dot{\infty} \dot{\omega}$

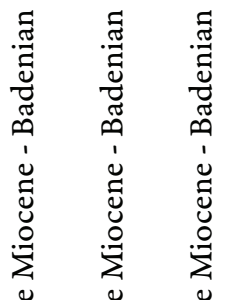

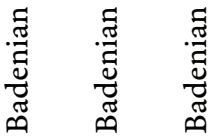

莺营营莺

苞

莺莺
$=: \quad:=$

मேं

苛芯芯

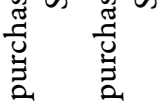

ฉ.

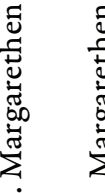

मे मे

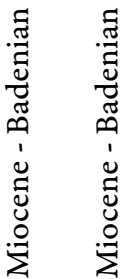

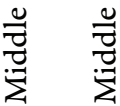

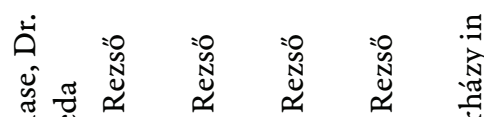

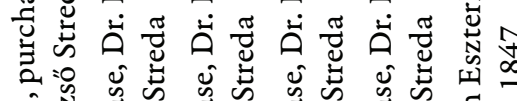

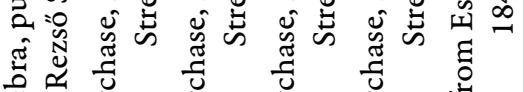

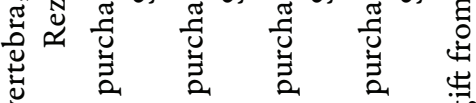
का

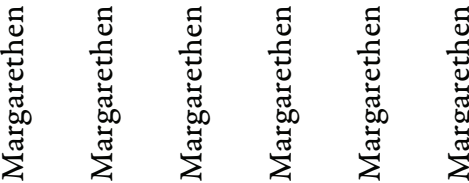

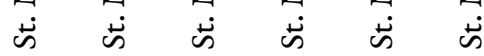

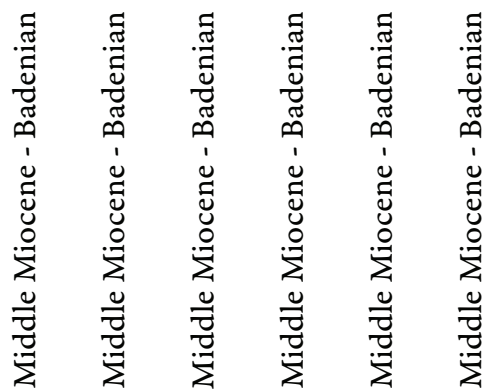

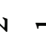

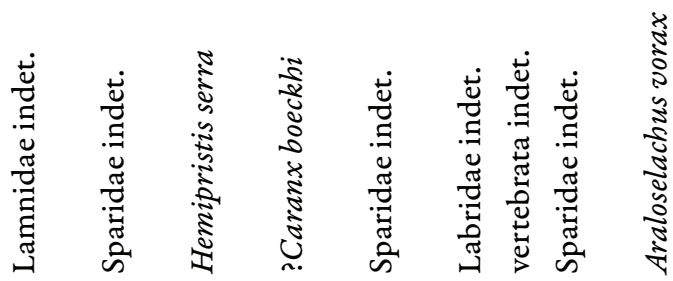

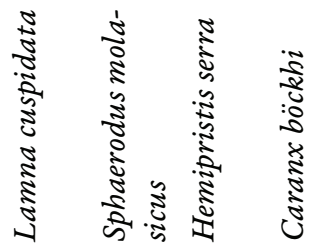

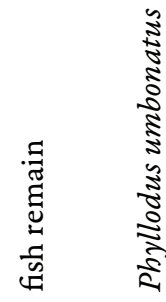

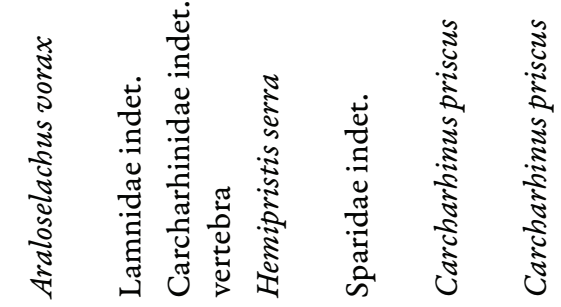

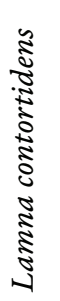

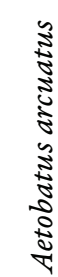

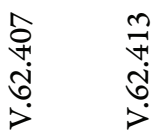

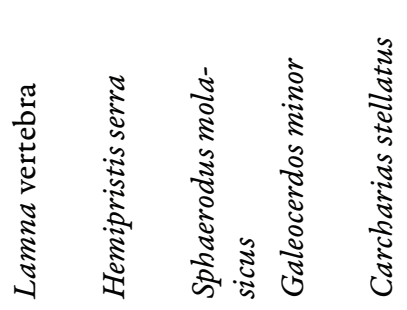

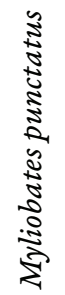

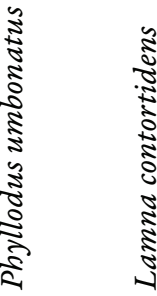

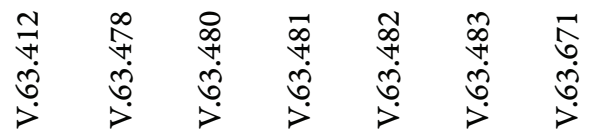

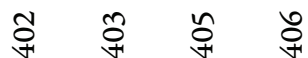
ஸे 


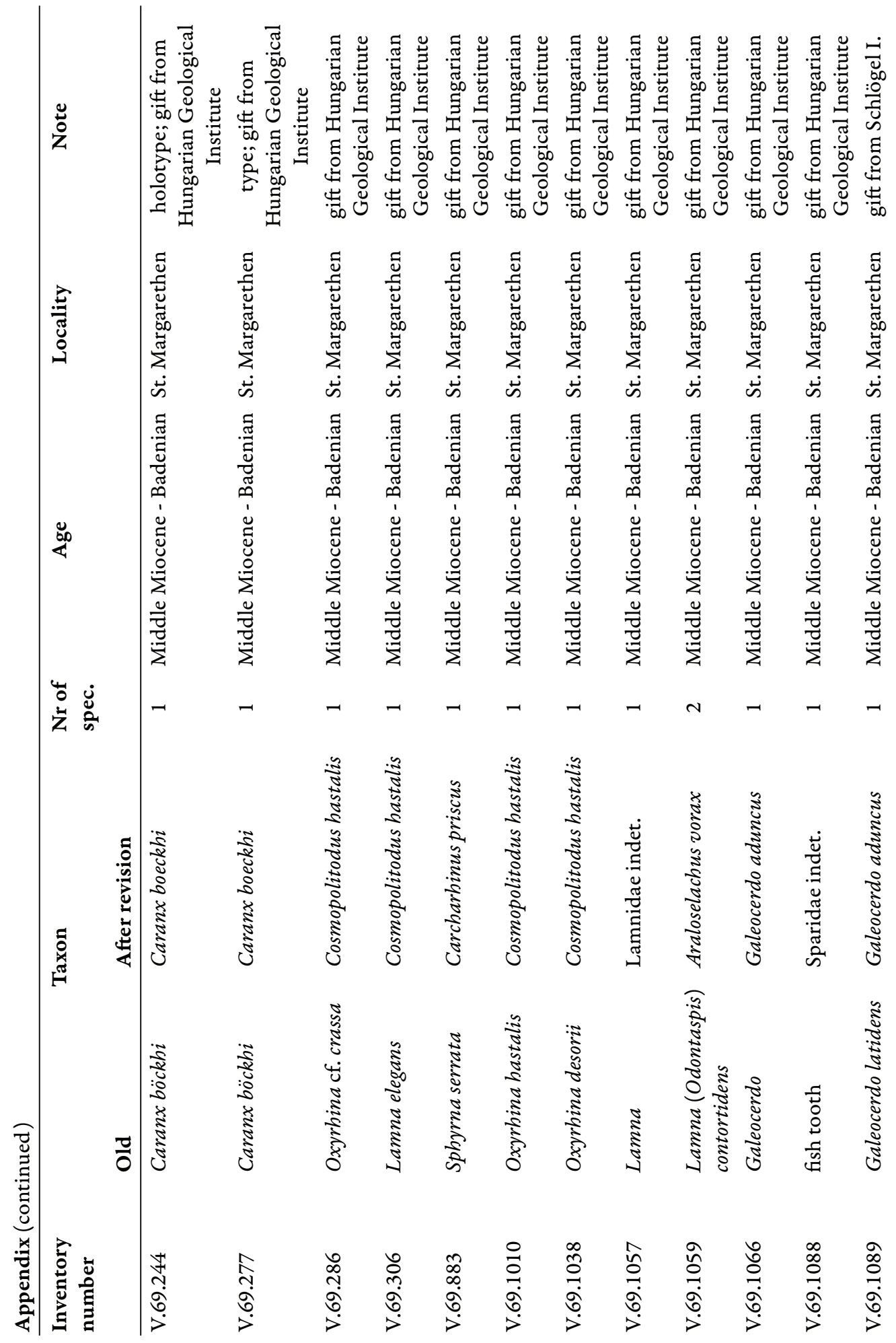




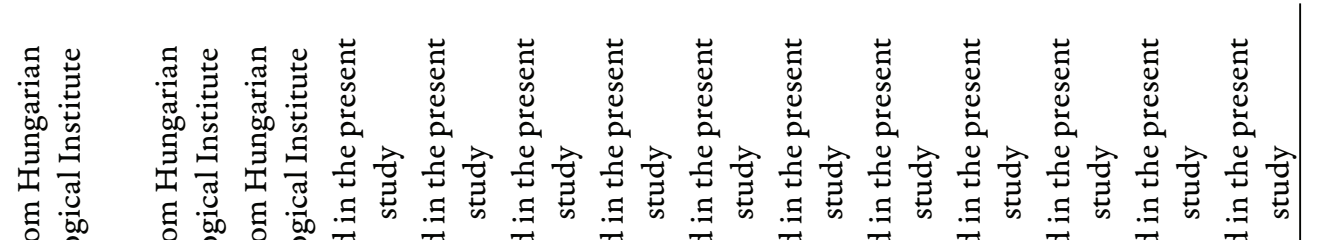

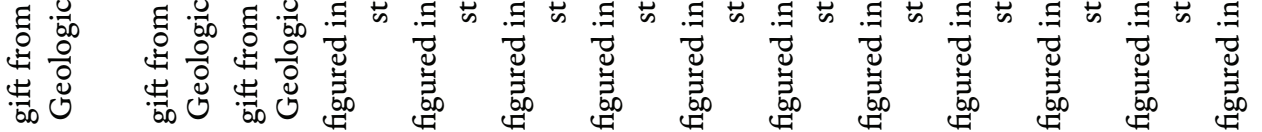

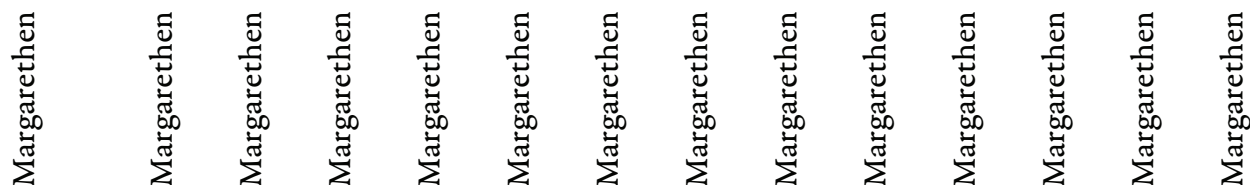

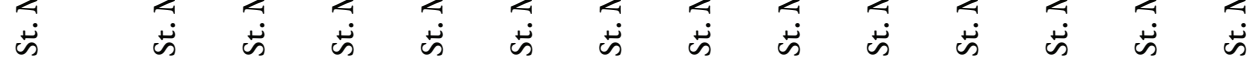

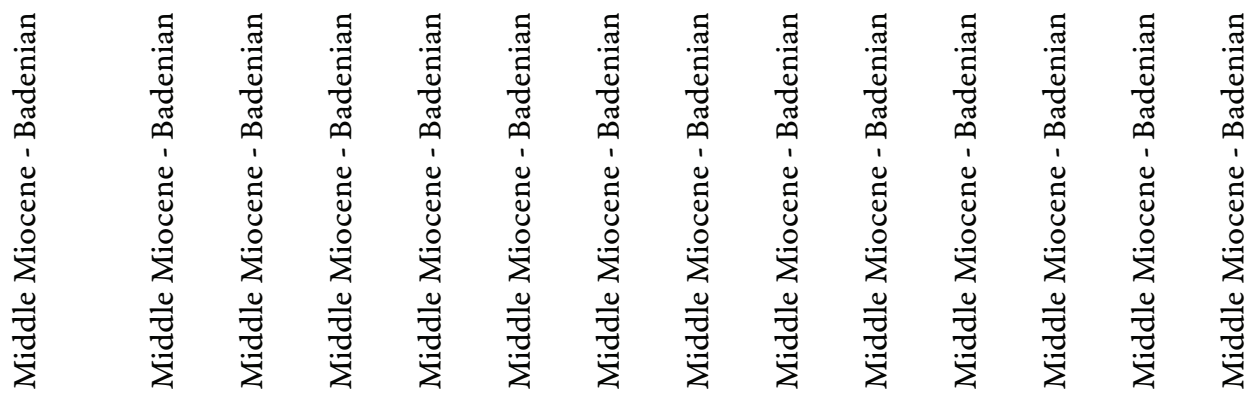

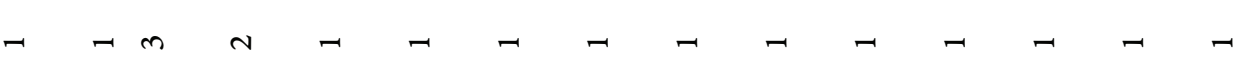

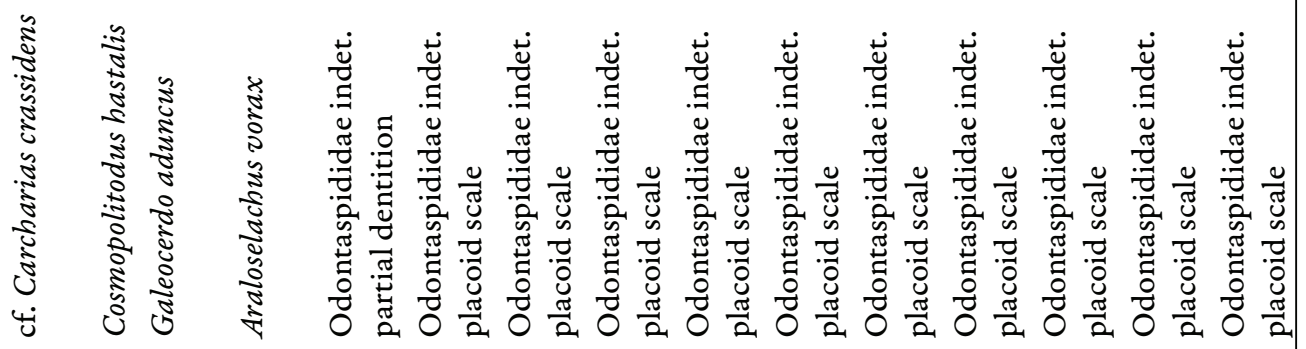

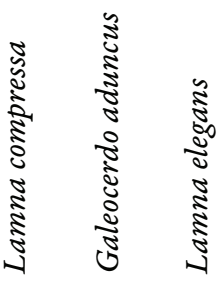

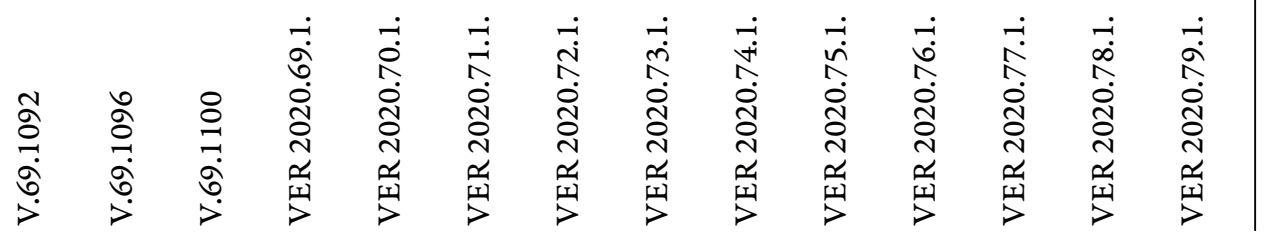




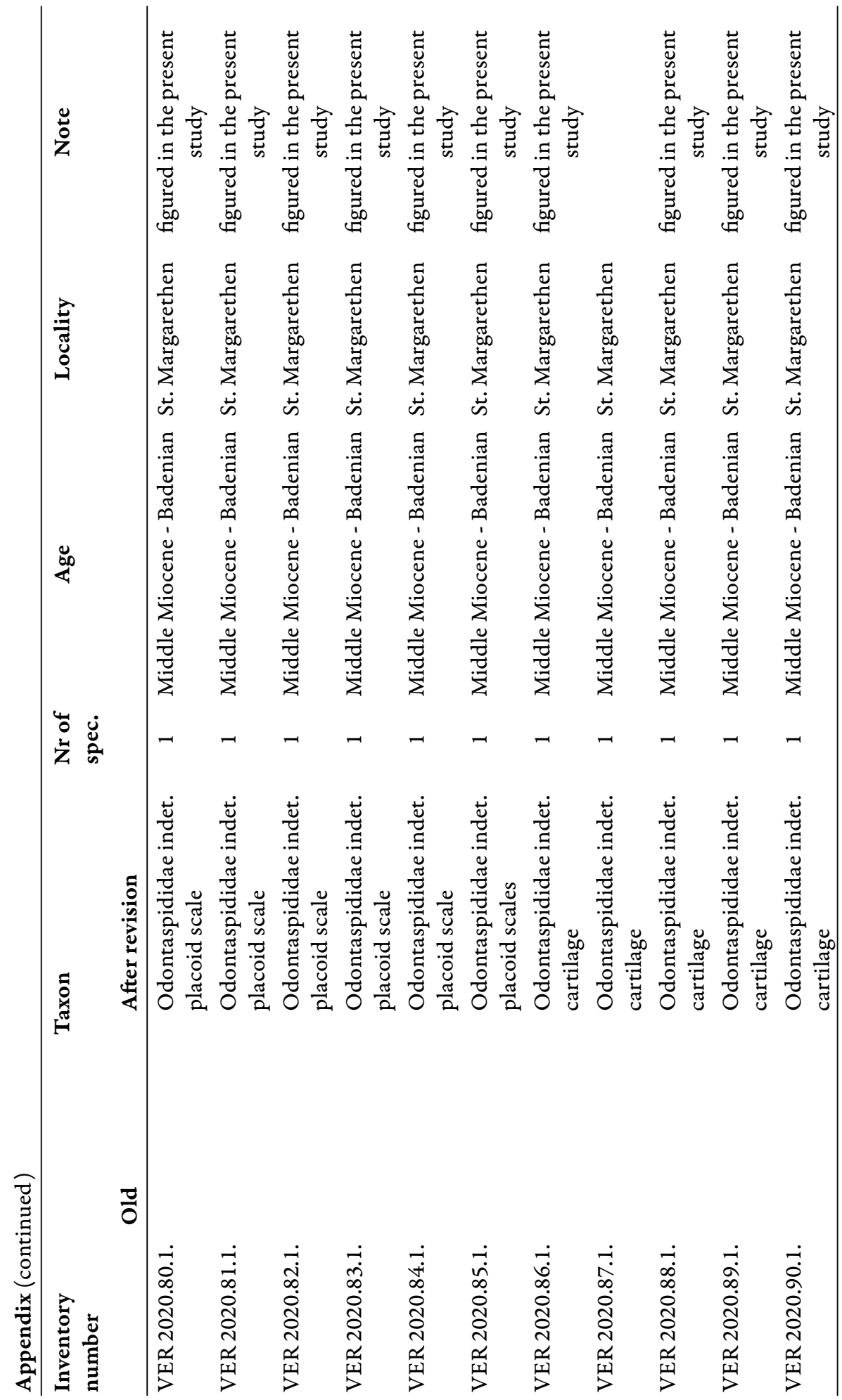

